\title{
THE DISTRIBUTION OF POLYCHAETA IN OFFSHORE DEPOSITS IN THE IRISH SEA
}

\author{
By Eve C. SOUthWARD \\ Marine Biological Station, Port Erin ${ }^{1}$
}

(Text-figs. I and 2)

The bottom fauna of the Irish Sea around the Isle of Man and off the coast of Cumberland has been investigated by Dr N. S. Jones, who has described the fauna in general (1940, I951, 1952) and the Amphipoda in particular (1948). Apart from the Amphipoda the smaller animals have remained relatively unknown. To extend this earlier work a survey of the polychaetous worms was carried out during $1952-54$, and this paper deals with their distribution and ecology in the offshore bottom deposits. New records and details of taxonomic interest have been published elsewhere (Southward, 1956).

I am indebted to Dr N. S. Jones, Mr J. S. Colman and Dr A. J. Southward for advice and assistance; to $\mathrm{Mr} \mathrm{N}$. A. Holme for help with the mechanical analysis and to the University of Liverpool and the D.S.I.R. for financial assistance. The field work was carried out from the Marine Biological Station, Port Erin.

\section{THE AREA INVESTIGATED}

The area investigated during the $1952-54$ survey was roughly the same as that studied by Jones (195I). To begin with all the collections were made within Io miles of Port Erin but later the area was extended to include the deeper water to the west (Fig. I).

The coastline of the southern half of the Isle of Man is steep and rocky and, except in the bays, the sea bottom slopes sharply from low-water mark to Io fm. Below this depth the slope is more gradual and on the west side of the island the $50 \mathrm{fm}$. line is reached about ro miles offshore. There is a channel about $70 \mathrm{fm}$. deep between the Isle of Man and Ireland. The sea to the south and east is shallower, the bottom is more irregular, and between the Isle of Man and England the depth rarely exceeds 20 fathoms.

The offshore grounds present a variety of habitats, most of which can be found within Io miles of Port Erin. The deposits have been classified by Jones (195I) into four main types: (a) coarse sands, gravels including shell

\footnotetext{
${ }^{1}$ Present address: The Laboratory, Citadel Hill, Plymouth.
} 


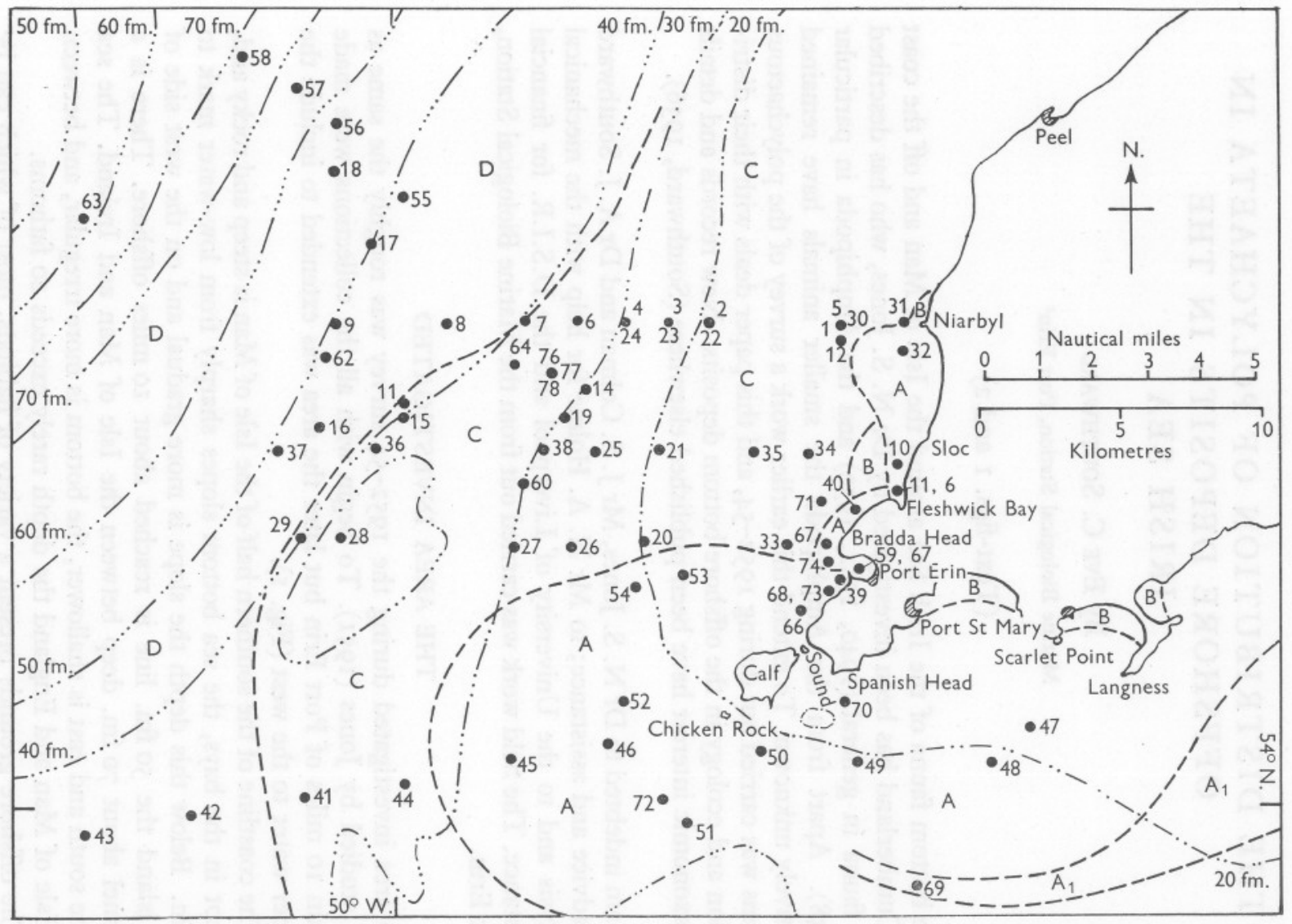

Fig. I. Map of the south end of the Isle of Man, showing positions of offshore stations (numbers as in Table II). The heavy broken lines mark the approximate limits of the various deposits. A gravels ( $\mathrm{A}_{1}$ Modiolus epifauna); $\mathrm{B}$ clean sand; C muddy sand; D mud. 
and stony gravels; $(b)$ fine sand; $(c)$ muddy sand; $(d)$ mud. The approximate limits of these types of deposit (as determined by Jones) are marked by the heavy broken lines in Fig. I. The deposits grade into one another and there are no sharp boundaries between them.

In this area the main factor controlling the grade of a deposit appears to be the amount of water movement over it. The tidal currents reach $3 \frac{1}{2}$ knots at spring tides along the south coast of the island, and in places $4 \frac{1}{2}$ knots. There are weaker currents inshore along the west coast, but in a large area to the west of the island they are too slight to be perceptible (West Coast of England Pilot, 1948). It is in this area that soft deposits are present in relatively shallow water. Wave action may be felt down to $25 \mathrm{fm}$., as this is the least depth at which mud is found (Jones, I95I).

The surface temperature of the sea off the south-west coast had a mean annual range of $6.5^{\circ} \mathrm{C}$ during 1903-12, according to Matthews (I9I4). The monthly mean was lowest in February, at $7.5^{\circ} \mathrm{C}$ (all depths) and highest in August at $13^{\circ} \mathrm{C}$. At this time of year the bottom temperature was less than $10^{\circ} \mathrm{C}$; it reached its maximum in November when the temperature at all depths was $12^{\circ} \mathrm{C}$. During 1953 (Slinn, 1956) the temperature was lower than the mean in February (6-7 6 at all depths) and higher than the mean in August $\left(13.5-15^{\circ} \mathrm{C}\right.$ at the surface and $\mathrm{II} \cdot 5^{\circ} \mathrm{C}$ at $50 \mathrm{fm}$.). The maximum bottom temperature was recorded in October $\left(\mathrm{I} 3 \cdot 3-\mathrm{I} 3 \cdot 7^{\circ} \mathrm{C}\right)$.

The salinity of the sea in the same area is about $34 \%$ with an annual variation of about $0.2 \%$ (Matthews, I9I4).

\section{METHODS}

\section{GEAR USED}

Several different types of gear were used for obtaining bottom samples. The most useful was a van Veen type of grab sampler taking a sample of one-tenth of a square metre (Thamdrup, 1938). The depth to which this instrument would dig depended on the hardness of the deposit. It was most efficient on mud and muddy sand, where it probably dug to at least $15 \mathrm{~cm}$. Dredges were used on deposits too hard for the grab sampler. A small naturalist's dredge, with a bowed frame ( $\mathrm{I} \mathrm{ft} .6 \mathrm{in}$. wide) and a stramin bag, was used for fine gravel or gravel mixed with sand; judging from the fragments of Ensis sp. sometimes brought up it could dig $4-8 \mathrm{~cm}$ into these deposits. A larger naturalist's dredge ( $2 \mathrm{ft}$. 6 in.) was occasionally employed on sand and fine gravel but was less efficient than the smaller one. Where the bottom was composed of coarse gravel a scallop dredge ( $4 \mathrm{ft}$. wide and lined with $\frac{3}{8}$ in. netting) was found most useful since the stramin of the small dredge was easily torn. It brought up only the coarse gravel and large stones, any fine material being washed out while the dredge was being hauled to the surface. 
Depths were measured with an echo sounder and the positions of the stations calculated from compass bearings. A list of stations is given in Table II, and their positions are marked on Fig. I.

\section{TREATMENT OF COLLECTIONS}

The contents of the scallop dredge were examined on board the boat, larger specimens being picked out and samples of stones, shells and hydroids kept for more detailed examination. The samples taken in the naturalist's dredges were not sorted on board, but the whole or part of the sample was taken back to the laboratory. Grab samples were washed through a $2 \mathrm{~mm}$ round-holed sieve with a jet of water from a hose, on board the boat, after which the entire residue on the sieve was retained for examination in the laboratory.

At the laboratory samples and specimens were either examined fresh, soon after arrival, or preserved, without sorting, in $5 \%$ sea water formalin.

Weeds, hydroids and shells were searched carefully, usually under a dissecting microscope, and the worms picked out. Gravel was sorted in two stages: first, the larger animals were picked out by hand, then the gravel was washed several times and the washing waters strained through fine bolting silk. In this way many small animals were retained, that would otherwise have been lost. The first residue from the grab samples was treated in the same way if it contained much gravel. If not, it was sorted by hand.

In the case of the grab samples, and those of the small dredge, all the macrofauna was preserved and the animals other than polychaetes identified at least as far as phyla. When the scallop dredge was used only the polychaetes were picked out, but notes were made on the abundance of other animals.

After identification the polychaetes were preserved in $70 \%$ alcohol, and a representative collection of species has been stored at Port Erin.

\section{GRADE ANALYSIS OF DEPOSITS}

Small samples of most types of offshore deposit were taken from hauls of the grab sampler and small dredge. These samples were dried and later subjected to the method of grade analysis used by Holme (1954). This method separates the sample into eight grades of particles: (i) over $2 \mathrm{~mm}$ diameter; (ii) $2-\mathrm{I} \mathrm{mm}$; (iii) $\mathrm{I}-0.5 \mathrm{~mm}$; (iv) $0.5-0.25 \mathrm{~mm}$; (v) $0.25-0.2 \mathrm{I} \mathrm{mm}$; (vi) $0.2 \mathrm{I}-0.124 \mathrm{~mm}$; (vii) $0.124-0.0313 \mathrm{~mm}$; (viii) less than $0.0313 \mathrm{~mm}$. In addition, fragments over $10 \mathrm{~mm}$ in diameter were separated from the first group.

\section{TAXONOMY}

The names and classification used here are mainly those used by Fauvel (1923, 1927). Some of the species identified during the present survey are not included by Fauvel; references to descriptions of these are given in the taxonomic paper referred to above (Southward, 1956). 


\section{BOTTOM DEPOSITS}

During the field work bottom deposits were identified fairly readily as belonging to the four main groups described by Jones (I95I), but several subgroups could also be recognized.

The coarse grounds (Fig. I, A) include more than one type of gravel. A wide area to the south of the Isle of Man is occupied by large stones, shells and coarse shell gravel and the same type of coarse shell gravel also occurs on

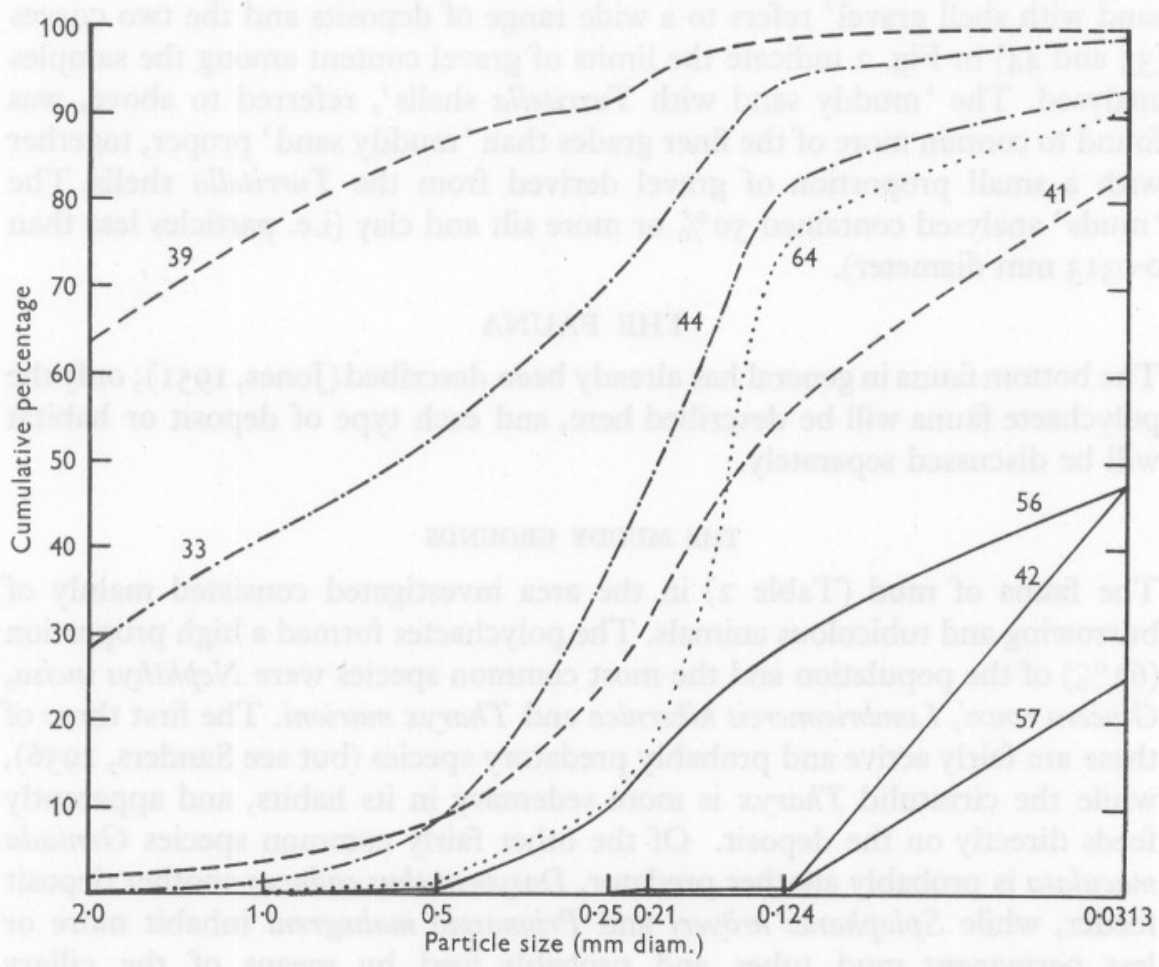

Fig. 2. The composition of various bottom deposits shown by means of cumulative curves, Station numbers as in Table II. - - - , fine stony gravel; $-\cdot \cdot \cdot \cdot-\cdot-$, muddy sand with shell gravel; $\cdots \cdots$, muddy sand; -.---, muddy sand with Turritella shells; mud.

the west side of the island, off Bradda Head. Further north, between Fleshwick Bay and Niarbyl, there are deposits of fine stony gravel, which in places is mixed with larger stones or with nodules of coralline algae (Lithothamnion sp.). This algal deposit, mixed with muddy sand, also occurs to the west of Niarbyl.

Towards the outer limits of the coarse grounds the gravel is mixed with muddy sand, the proportion of which increases with depth until the pure 
muddy sand grounds are reached (Fig. I, C). The muddy sand in turn grades into mud in deeper water, and along the edges of the mud grounds (Fig. I, D) the muddy sand may contain large numbers of empty shells of Turritella communis Lamarck.

Mechanical analysis (see p. 52) of the deposits from fourteen stations has shown that the differences noticed in the field were definitely differences in grade composition. The composition of the various deposits (Table I) can be shown graphically by means of cumulative curves (Fig. 2). The term 'muddy sand with shell gravel' refers to a wide range of deposits and the two curves ( 33 and 44 ) in Fig. 2 indicate the limits of gravel content among the samples analysed. The 'muddy sand with Turritella shells', referred to above, was found to contain more of the finer grades than 'muddy sand' proper, together with a small proportion of gravel derived from the Turritella shells. The 'muds' analysed contained $50 \%$ or more silt and clay (i.e. particles less than $0.0313 \mathrm{~mm}$ diameter).

\section{THE FAUNA}

The bottom fauna in general has already been described (Jones, I95I); only the polychaete fauna will be described here, and each type of deposit or habitat will be discussed separately.

\section{THE MUDDY GROUNDS}

The fauna of mud (Table 2) in the area investigated consisted mainly of burrowing and tubicolous animals. The polychaetes formed a high proportion $(62 \%)$ of the population and the most common species were Nephthys incisa, Glycera rouxi, Lumbriconereis hibernica and Tharyx marioni. The first three of these are fairly active and probably predatory species (but see Sanders, I956), while the cirratulid Tharyx is more sedentary in its habits, and apparently feeds directly on the deposit. Of the other fairly common species Goniada maculata is probably another predator, Dasybranchus caducus another deposit feeder, while Spiophanes kröyeri and Prionospio malmgreni inhabit more or less permanent mud tubes and probably feed by means of the ciliary currents of the tentacles. A few species seem to be confined to mud; these are Leanira tetragona, Paraonis gracilis, Dasybranchus caducus, Clymene gracilis and Rhodine loveni, but all except Dasybranchus were rare, even in mud.

Thus, the majority of the polychaetes found in mud were either active, predatory species or non-selective deposit feeders. Selective deposit feeders, such as the spionids, were few, and the specialized filter-feeding sabellids and serpulids were absent.

\section{THE MUDDY SAND GROUNDS}

Where the bottom deposit was muddy sand with little or no gravel the main members of the polychaete fauna were the same as those of mud, but the 
number of species present and the total population were much greater (Table 3 ). Nephthys incisa and Glycera rouxi were as abundant as in the mud, but Lumbriconereis hibernica and Tharyx marioni were rather less common. Goniada maculata, Lumbriconereis gracilis, Spiophanes kröyeri, Chaetozone setosa, Diplocirrus glaucus, Owenia fusiformis, Myriochele heeri, Amphicteis gunneri, Trichobranchus glacialis and Terebellides stroemi were all fairly common and characteristic species of this deposit. Most of these are sedentary species feeding on the deposit. Owenia has a crown of short ciliated tentacles with which it collects food as well as building its tube (Watson, 1900); Myriochele (a closely related species), though without tentacles, has a ciliated oral funnel with which it sets up a feeding current, and by closing this funnel it is able to reject unwanted particles. Spiophanes, Diplocirrus, Amphicteis and the terebellids probably feed by means of their ciliated tentacles (Blegvad, 1915; Hunt, I925; Nicol, 1930; Mare, 1942; Dales, 1955). The cirratulid Chaetozone appears to feed directly on the deposit.

Among this largely burrowing and tubicolous polychaete population surface-living species were few, but probably all the aphroditids, except Panthalis, live on the surface of the deposit. Some of the tubicolous forms are dependent on sand grains or shell fragments for the formation of their tubes, for example Owenia, Myriochele and Pectinaria spp.; these are absent from mud and most common in the coarser muddy sands. Moreover, Pectinaria has a specialized method of feeding through a funnel in the deposit (Watson, 1928), which probably requires a fairly firm deposit for its construction.

\section{MUDDY SAND WITH SHELL GRAVEL}

Where shell gravel was mixed with the muddy sand the fauna was much richer, since it included most of the muddy sand species together with many of those from shell gravel; the number of species of Polychaeta (I22) found in this deposit was greater than in any other investigated. The average density of the population was also fairly high $\left(22 \mathrm{I}\right.$ per $\left.\mathrm{m}^{2}\right)$ though it formed less than $50 \%$ of the macrofauna. Most of the common species were burrowing or tubicolous, but with a greater gravel content the number of wandering and fixed species increased.

The most abundant species were Lumbriconereis gracilis, L. hibernica and Owenia fusiformis; the latter occurred at all stations and sometimes exceeded Ioo per $\mathrm{m}^{2}$ (Table 4 ). The other two were almost equally widely distributed but were less numerous. The other characteristic species of this mixed deposit were mainly burrowers and included Nephthys incisa, Glycera rouxi, Goniada maculata, Eone nordmanni, Notocirrus scoticus (all probably predators), Laonice cirrata, Heterocirrus zetlandicus, Myriochele heeri, Amphicteis gunneri and Pectinaria auricoma (deposit feeders of various types). The serpulid Hydroides norvegica was common on the larger shell fragments.

Polynoids, phyllodocids and syllids were more common in this mixed 
deposit than in muddy sand alone and many species of the two latter groups were found in crevices in shell fragments. The sabellid Potamilla reniformis was also found in crevices, two others (Euchone rubrocincta and Chone suspecta) were found, apparently free-living, among gravel.

Fine shell gravel

THE FINE GRAVEL GROUNDS

Of the fine gravels the fine shell had the richest fauna, and the polychaetes formed a higher proportion of the total macrofauna than in the other two. This deposit also contained the greatest number of polychaetes per square metre of any of the grounds investigated with the grab sampler, although this was the ground on which the grab obtained the smallest samples. Thus, the population may be considerably greater than that shown by this survey.

The most common polychaetes (Table 5) were Pholoë minuta, Syllis armillaris, Glycera lapidum, Nematonereis unicornis, Laonice cirrata, Aonides paucibranchiata, Owenia fusiformis, Polycirrus denticulatus and Hydroides norvegica. The first four of these are active and may be carnivorous, Laonice does not seem to form a permanent tube and its large eye-spots suggest that it also has an active mode of life, but its feeding is probably ciliary, as in other spionids. The only common tubicolous polychaete among the infauna was Owenia fusiformis. Onuphis conchylega and Eunice harassi were found occasionally among the epifauna; these two species build tubes of gravel and shell fragments but, unlike Owenia, they can move about, dragging their tubes with them (Watson, 1903).

Sabellids and serpulids were common in fine shell gravel, the serpulids being attached to shell fragments. These two groups appear to be most common where there is some water movement.

Fine stony gravel

The fine stony gravels provide a rather similar habitat to the shell gravel but the density of the population appears to be lower. However, as the grab sampler was not used, this conclusion is only tentative. The percentage of polychaetes in the total population was lower than in either of the other fine gravels. Glycera lapidum, Capitomastus minimus, Aonides paucibranchiata and Pista cristata were the most common species (Table 5), except at station 34, where the gravel was mixed with muddy sand and large stones. Here many of the species were more characteristic of muddy sand than of stony gravel. Scalisetosus pellucidus was probably commensal with the ophiuroid Ophiothrix fragilis, which was present in large numbers.

\section{Coralline gravel}

The 'coralline' gravels were composed of irregular nodules of a species of Lithothamnion, mixed with muddy sand. While some of the animals were 
characteristic of muddy sand, the fauna as a whole had more in common with that of the fine gravels. The polychaetes formed nearly $60 \%$ of the total macrofauna and the most common species were Pholoë minuta, Lumbriconereis gracilis, Glycera lapidum, Nematonereis unicornis, Laonice cirrata, Capitomastus minimus and Pista cristata (Table 5). Lumbriconereis gracilis appeared to be most common in mixed deposits of muddy sand and gravel, while Capitomastus and Pista cristata were more characteristic of stony gravels. The other species were common in fine shell gravel.

Thus, the polychaete fauna of all the fine gravels consisted mainly of active species, some burrowing (notably Glycera lapidum) and some living on the surface. Tubicolous species were few, except for the serpulids of the shell gravels. Few of the species feed directly on the deposit, without selection, and many of the active ones are probably predators.

\section{THE COARSE GRAVEL GROUNDS}

The fauna of coarse gravels appeared to be poorer than that of the fine gravels, but it is possible that further sampling and more careful examination of the gravel would reveal more species. Many tubicolous polychaetes were found in cracks and holes, but the external species were rather few and corresponded to the epifauna of the fine gravels. The common species of Polychaeta were mainly polynoids, sabellids and serpulids. Halosydna gelatinosa was fairly common, Platynereis dumerilii was frequent where there were fragments of algae among the gravel (it has been observed feeding on these), and the terebellid Polymnia nebulosa was common on large shell fragments. Both Platynereis and Polymnia inhabit semi-permanent mucous tubes. The serpulids occurred on shells and stones; Pomatoceros triqueter was the most common, being found on most shells and stones in every haul, while Serpula vermicularis and Hydroides norvegica were less common than Pomatoceros but nevertheless fairly frequent. Sabellaria spinulosa formed tubes of sand on shells and was widely distributed though not abundant.

Large stones had a surface fauna of Pomatoceros and Hydroides together with some polynoids, but the latter were more common in holes and crevices (Table 6). An examination of several lumps of limestone bored by Hiatella (station 50) showed the most common crevice-living species to be Lepidonotus squamatus, Syllis armillaris, Autolytus aurantiacus and Polydora caeca. The bigger holes in a large rock from station 74 contained many Polymnia nebulosa and several Dasychone bombyx, but the smaller species were not fully investigated. At station 32 the coarse stony gravel was mixed with muddy sand and the fauna as a whole was rather sparse, consisting mainly of muddy sand species, though the polynoid Harmothoe impar was common on the stones. 
Crevices and holes in shells

The fauna of crevices in shells included many of the species found in holes in stones and also some boring forms. Of the polychaetes, only some species of Polydora and Dodecaceria are definitely known to bore into shells (e.g. Söderström, I923), but it is possible some other species may do so. The burrows of Polydora, Cliona (the boring sponge) and Phoronis ovalis Wright were common in shells and shell fragments, and these were utilized by many other animals, some of which form their own tubes inside. The polychaetes appeared to be the most common animals in this habitat and thirty-two species were found (Table 7). The commonest and most widespread were Syllis armillaris, Nematonereis unicornis, Polydora caeca, Polycirrus denticulatus and Potamilla reniformis, but Syllis variegata, Autolytus aurantiacus, Polydora ciliata, P. flava and Lumbriclymene minor were sometimes common. Syllids and phyllodocids were abundant in this habitat but only one aphroditid, Pholoë minuta, was found. Oyster shells (Ostrea edulis L.) contained a large number of species but those of other molluscs (Modiolus, Pecten and Glycimeris) had a poorer fauna. Many of the species found in shells also inhabited the empty tubes of serpulids.

\section{Hydroids}

Several species of hydroids were common on shells and stones in the gravel deposits. They had a characteristic fauna, consisting mainly of polychaetes (Table 8), which differed from the gravel fauna. The serpulids Hydroides norvegica and Spirorbis spirillum were common, the latter often abundant. Many syllids lived among the branches, usually in their own mucous tubes, and several aphroditids were found, though some of these may have been inhabitants of the gravel on which the hydroids grew. Members of these two families may feed on the hydroids, but most of the other polychaetes are detritus - or filter-feeders.

\section{Sponges}

Sponges as well as hydroids are part of the epifauna of coarse gravel, and they also have a typical fauna. They were most frequent on and among the shells of Modiolus modiolus (L.), which are common in an area to the southwest of the Isle of Man (Fig. I, $A_{1}$ ). This fauna has not been much investigated, but Syllis spongicola seems to be the most characteristic species. A few other syllids were found, notably $S$. armillaris, but they were also common species on hydroids and gravel.

\section{THE CLEAN SAND GROUNDS}

The offshore clean sand (Fig. I, B) was sampled only in Port Erin Bay and off Niarbyl. A series of grab samples taken in Port Erin Bay (Table 9, 
station 59) indicated a fauna fairly rich in species of polychaetes and similar to that found at E.L.W.S. on the beach (c.f. Pirrie, Bruce \& Moore, I932; Moore, I933). The grab sampler did not dig very deeply on this sand and the samples cannot have included the deeper burrowing animals; however, the number of animals per $\mathrm{m}^{2}$ at $3-4 \mathrm{fm}$. exceeded the number found at E.L.W.S. on the beach. Two dredge hauls in the bay (65) brought up rather more surface-living species than the grab sampler. The common polychaetes, on or near the surface, were Sthenelais limicola, Kefersteinia cirrata and Pista cristata, while the common tubicolous and burrowing species were Scoloplos armiger, Chaetozone setosa and Clymene oerstedii. None of the three surfaceliving species has been found in the sandy beach, but Scoloplos is a characteristic intertidal species and Clymene is fairly common around and below M.L.W.S.

A small area of sand near Niarbyl was also sampled (3I) and Scoloplos armiger and Heterocirrus zetlandicus were found to be common. Single specimens of Nephthys cirrosa were taken at Niarbyl and Port Erin, and the species may be common in the lower layers of the sand, which were not reached by either the grab sampler or the dredge.

\section{DISCUSSION}

The results of this survey indicate that many species of Polychaeta are widely distributed in the various types of habitat examined, but that, nevertheless, the polychaete fauna of each is distinctive. The density of the population varies very much with the type of deposit, as does the number of species present (Table Io). Environmental factors, apart from differences in the deposit, appear to have little effect on the fauna. Any direct effect of water movement on the fauna is masked by its effect on the composition of the deposit and these two factors cannot be separated. Differences in depth, unaccompanied by differences in the deposit, appear not to have much influence on the composition of the fauna. However, the depths in the area studied are comparatively small.

Most of the habitats examined were composite. That is, the softer deposits contained gravel and the gravels contained some sand or muddy sand. This may account for the wide distribution of some species. For example, seven species were found in all four main types of deposit but, of these, four glycerids, Glycera rouxi, G. gigantea, Goniada maculata and Eone nordmanni, are more characteristic of soft deposits and only occur in gravel where it is mixed with sand or muddy sand. Nematonereis unicornis occurs in all four deposits but is always associated with gravel, often living in crevices in shell fragments. The other two species, Mystides limbata and Glycera convoluta, are not common in any deposit and their distribution is rather sporadic.

The extent of the distribution of each species appears to depend mainly on 
its mode of life and feeding habits. Thus, carnivorous species are found in all habitats, but the burrowing forms, such as Nephthys, are restricted to the softer deposits, while the surface-living forms, such as the aphroditids, are more common on the harder grounds. Tubicolous species, such as Owenia and Pectinaria, are limited in their distribution by their dependence on definite sizes of particles for the formation of their tubes, while the serpulids require hard substrata for the attachment of their calcareous tubes. The distribution of filter-feeders may be limited by high concentrations of silt in the water, for no serpulids or sabellids were found in the mud, and few were found in the muddy sand (cf. Loosanoff \& Tommers, 1948).

There were many examples of related species, of similar body form, being found in very different types of deposit. Thus, the Capitellidae were represented by Dasybranchus caducus in mud, Notomastus latericeus in muddy sand, Capitomastus minimus in fine gravel and Capitella capitata in sand. Again, the common species of Lumbriconereis (Eunicidae) in mud and muddy sand was $L$. hibernica, while $L$. fragilis was characteristic of coarse gravel and $L$. gracilis was common in the intermediate types of deposit. The factors involved in the distribution of these species may include the method of reproduction and the larval development and settlement (cf. Thorson, 1950; Wilson, 1952), as well as possible differences in feeding habits or food. Unfortunately, very little information is available on the reproduction of any species, since sampling was insufficient for detailed investigation of the breeding period or annual fluctuations in the population of the various species.

The numerical proportion of polychaetes was high in comparison with the other main faunistic groups at all stations where the animals were counted (Table 10). However, on the muddy grounds the heart-urchin Brissopsis and the crustacean Calocaris appear to form the greater part of the population by weight, though present in small numbers, and in the coarser grounds the Mollusca (or sometimes the Ophiuroidea) probably form the greatest proportion.

The density of the polychaete population on the grounds surveyed is low compared with that of some other British localities, and the species rarely attain the maximum size recorded by other authors. The maximum population found was 575 polychaetes per $\mathrm{m}^{2}$ (station 19), and this compares badly with, for example, the 2000 per $\mathrm{m}^{2}$ in the Rame mud near Plymouth (Mare, 1942).

The paucity of the fauna may be correlated with the low biomass found by Jones (1951, 1952) for the offshore grounds of the Isle of Man, compared with the grounds off the Cumberland coast. He considered that the low biomass was associated with a low run-off from the land in the area, and a low concentration of organic matter in the bottom deposits. 


\section{SUMMARY}

During 1952-54 a survey was made of the Polychaeta living in the offshore bottom deposits of the south of the Isle of Man. These deposits range from stones and coarse gravel to soft mud; samples were obtained with a van Veen grab sampler and various dredges.

It was found that, although some species were widely distributed, each bottom deposit had a typical fauna, and that where the deposits graded into one another the polychaete fauna was also mixed. The distribution of each species appears to depend mainly on its mode of life and feeding habits; some can exist in several types of deposit or habitat, while others are very much restricted in their distribution.

The Polychaeta formed a high proportion, numerically, of the macrofauna, exceeding any other animal group, except possibly in the coarse gravels. However, the density of the polychaete population was low compared with other areas of the British Isles, and this may be correlated with the comparatively low biomass in the area.

\section{REFERENCES}

Admiralty, Hydrographic Department, 1948. West Coast of England Pilot. 9th ed. London.

BLEGVAD, H., I9I5. Food and conditions of nourishment among the communities of invertebrate animals found on or in the sea bottom in Danish waters. Rep. Danish biol. Sta., Vol. 22, pp. 43-78.

Dales, R. P., 1955. Feeding and digestion in terebellid polychaetes. F. mar. biol. Ass. U.K., Vol. 34, pp. 55-79.

Fauvel, P., 1923. Polychètes errantes. Faune Fr., No. 5, 488 pp.

- 1927. Polychètes sédentaires. Faune Fr., No. 16, 494 pp.

Holme, N. A., I954. The ecology of British species of Ensis. F. mar. biol. Ass. U.K., Vol. 33, pp. I45-72.

Hunt, O. D., I925. The food of the bottom fauna of the Plymouth fishing grounds. F. mar. biol. Ass. U.K., Vol. 13, pp. 560-99.

JonEs, N. S., 1940. The distribution of the fauna and bottom deposits off Port Erin. Proc. Lpool biol. Soc., Vol. 53, pp. I-34.

— I948. The ecology of the Amphipoda of the south of the Isle of Man. F. mar. biol. Ass. U.K., Vol. 27, pp. 400-39.

- I95I. The bottom fauna off the south of the Isle of Man. F. Anim. Ecol., Vol. 20, pp. 132-44.

- 1952. The bottom fauna and the food of flatfish off the Cumberland coast. F. Anim. Ecol., Vol. 21, pp. I82-205.

Loosanoff, V. L. \& ToMmers, F. D., I948. Effect of suspended silt and other substances on rate of feeding of oysters. Science, Vol. 107, pp. 69-70.

MARE, M. F., I942. A study of a marine benthic community, with special reference to the micro-organisms. F. mar. biol. Ass. U.K., Vol. 25, pp. 517-554.

MatTHEWs, D. J., I9I4. The salinity and temperature of the Irish Channel and the waters south of Ireland. Sci. Invest. Fish. Br. Ire., Vol. 4, pp. I-26.

Moore, H. B., I933. A comparison of the sand fauna of Port Erin Bay in 1900 and 1933. Proc. malac. Soc. Lond., Vol. 20, pp. 285-294. 
Nicol, E. A. T., I930. The feeding mechanism, formation of the tube and physiology of digestion in Sabella pavonina. Trans. roy. Soc. Edinb., Vol. 56, pp. 537-98.

PIRRIE, M. E., BRUCE, J. R. \& MOORE, H. B., I932. A quantitative study of the sandy beach at Port Erin. F. mar. biol. Ass. U.K., Vol. 18, pp. 279-96.

SANDERS, H. L., I956. The biology of marine bottom communities. Oceanography of Long Island Sound. X. Bull. Bingham oceanogr. Coll., Vol. 15, pp. 345-4I4.

SLINN, D. J., 1956. Phosphate and oxygen in sea water off the Isle of Man during the years 1952-54. Rep. mar. biol. Sta. Pt Erin, No. 68, pp. 30-8.

Söperström, A., I923. Úber das Bohren der Polydora ciliata. Zool. Bidr. Uppsala, Bd. 8, pp. 319-26.

Southward, E. C., 1956. On some Polychaeta of the Isle of Man. Ann. Mag. nat. Hist. Ser. 12, Vol. 9, pp. 257-79.

ThamdRup, H. M., I938. Der van Veen-Bodengreifer. Vergleichsversuche über die Leistungsfähigkeit des van Veen- und des Petersen-Bodengreifers. F. Cons. int. Explor. Mer, Vol. 13, pp. 206-12.

Thorson, G., 1950. Reproductive and larval ecology of marine bottom invertebrates. Biol. Rev., Vol. 25, pp. I-45.

Watson, A. T., I900. On the structure and habits of the Polychaeta of the family Ammocharidae. F. Linn. Soc. (Zool.), Vol. 48, pp. 230-60.

- 1903. Observations on the habits of the Onuphidae and on the internal structures with which they fortify their homes. Proc. Lpool biol. Soc., Vol. 17, pp. 303-18. 1928. Observations on the habits and life history of Pectinaria koreni Malmgren. Proc. Lpool biol. Soc., Vol. 42, pp. 25-60.

WILsON, D. P., I952. The influence of the nature of the substratum on the metamorphosis of the larvae of marine animals, especially the larvae of Ophelia bicornis. Ann. Inst. océangraph. Monaco, T. 27, pp. 49-156. 
TABLE 1. GRADE COMPOSITION OF SOME OFFSHORE DEPOSITS

Particle size (mm diameter)

\begin{tabular}{|c|c|c|c|c|c|c|c|c|c|c|c|}
\hline Station & $\begin{array}{c}>\text { IO } \\
\%\end{array}$ & $\begin{array}{c}\text { IO-2.0 } \\
\%\end{array}$ & $\begin{array}{c}2 \cdot 0-1 \cdot 0 \\
\%\end{array}$ & $\begin{array}{c}\mathrm{I} \cdot \mathrm{O}-\mathrm{O} \cdot 5 \\
\%\end{array}$ & $\underset{\%}{0.5-0.25}$ & $\begin{array}{c}0.25-0.21 \\
\%\end{array}$ & $\begin{array}{c}0.21- \\
0.124 \\
\%\end{array}$ & $\begin{array}{c}0.214- \\
0.0313 \\
\%\end{array}$ & $\underset{\%}{<0.0313}$ & Type of deposit & $\begin{array}{c}\text { Depth } \\
\text { (fm.) }\end{array}$ \\
\hline 39 & I6.8 & $49 \cdot 69$ & I2.77 & $10 \cdot 28$ & $4 \cdot 57$ & 3.45 & $4 \cdot 22$ & 0.84 & 0.28 & Fine stony gravel & 5 \\
\hline $\begin{array}{l}33 \\
35 \\
60 \\
45 \\
44\end{array}$ & $\begin{array}{c}14 \cdot 17 \\
6 \cdot 2 \\
0 \\
0 \\
0\end{array}$ & $\begin{array}{r}14.592 \\
2.737 \\
0.592 \\
6.070 \\
0.020\end{array}$ & $\begin{array}{r}12.633 \\
1.935 \\
3.069 \\
9.844 \\
1.270\end{array}$ & $\begin{array}{r}\text { II.972 } \\
5 \cdot 895 \\
8 \cdot 375 \\
9 \cdot 811 \\
6 \cdot 803\end{array}$ & $\begin{array}{l}17 \cdot 934 \\
28 \cdot 228 \\
30 \cdot 538 \\
21 \cdot 766 \\
29 \cdot 468\end{array}$ & $\begin{array}{r}5.432 \\
\text { II.790 } \\
\text { I } 2.549 \\
9.926 \\
I 0.143\end{array}$ & $\begin{array}{l}17.618 \\
30.609 \\
33.850 \\
23.571 \\
32.542\end{array}$ & $\begin{array}{r}4.407 \\
8.225 \\
5.385 \\
9.734 \\
12.623\end{array}$ & $\left.\begin{array}{l}1 \cdot 253 \\
4 \cdot 380 \\
5 \cdot 639 \\
9 \cdot 269 \\
7 \cdot 127\end{array}\right\}$ & Muddy sand and shell & $\left\{\begin{array}{l}17 \\
18 \\
31 \\
32 \\
34\end{array}\right.$ \\
\hline 64 & o & 0 & 0.165 & I.437 & $9 \cdot 125$ & $6 \cdot 139$ & $58 \cdot 652$ & $15 \cdot 126$ & $9 \cdot 349$ & Muddy sand & 37 \\
\hline $\begin{array}{l}4 \mathrm{I} \\
6 \mathrm{I}\end{array}$ & $\begin{array}{l}\circ \\
\circ\end{array}$ & $\begin{array}{l}2 \cdot 162 \\
0.082\end{array}$ & $\begin{array}{l}I \cdot 948 \\
0.60 I\end{array}$ & $\begin{array}{l}3 \cdot 934 \\
2 \cdot 405\end{array}$ & $\begin{array}{l}17.029 \\
10.032\end{array}$ & $\begin{array}{l}6.592 \\
4.756\end{array}$ & $\begin{array}{l}24 \cdot 136 \\
30 \cdot 836\end{array}$ & $\begin{array}{l}27 \cdot 609 \\
28 \cdot 403\end{array}$ & $\left.\begin{array}{l}16 \cdot 586 \\
22 \cdot 881\end{array}\right\}$ & $\begin{array}{l}\text { Muddy sand and Turritella } \\
\text { shells }\end{array}$ & $\left\{\begin{array}{l}35 \\
4 I\end{array}\right.$ \\
\hline $\begin{array}{l}43 \\
42\end{array}$ & $\begin{array}{l}0 \\
0\end{array}$ & $\begin{array}{l}0 \\
0\end{array}$ & $\begin{array}{l}0.080 \\
0.035\end{array}$ & $\begin{array}{l}0.040 \\
0.035\end{array}$ & $\begin{array}{l}0.080 \\
0.105\end{array}$ & $\begin{array}{l}0.040 \\
0.035\end{array}$ & $\begin{array}{l}0.240 \\
0.140\end{array}$ & $\begin{array}{l}50 \cdot 061 \\
47 \cdot 377\end{array}$ & $\begin{array}{l}49 \cdot 503 \\
52 \cdot 270\end{array}$ & & $\left(\begin{array}{l}35 \\
38\end{array}\right.$ \\
\hline 56 & ० & $0.14 \mathrm{I}$ & 0.100 & 0.463 & 9.651 & $5 \cdot 13^{8}$ & 13.439 & 19.021 & $52 \cdot 043$ & Mud & $\left\{\begin{array}{l}30 \\
58\end{array}\right.$ \\
\hline 57 & 0 & 0.033 & 0.067 & 0.067 & 0.067 & 0.033 & 0.336 & $24 \cdot 789$ & $74 \cdot 604$ & & 65 \\
\hline 58 & 0 & 0.028 & 0.056 & 0.056 & 0.085 & 0.056 & 0.226 & 29.553 & $69.935)$ & & 70 \\
\hline
\end{tabular}




\section{TABLE 2. POLYCHAET FAUNA OF MUD GROUNDS}

(As number per square metre.)

$\begin{array}{llllllllllllllllll}\text { Station number } & \ldots & 43 & 42 & 15 & 7 & 16 & 8 & 9 & 17 & 37 & 62 & 55 & 18 & 56 & 63 & 57 & 58\end{array}$ $\begin{array}{lllllllllllllllllllll}\text { Depth (fathoms) } & \cdots & 35 & 38 & 40 & 40 & 45 & 45 & 50 & 50 & 50 & 50 & 53 & 55 & 58 & 60 & 65 & 70\end{array}$

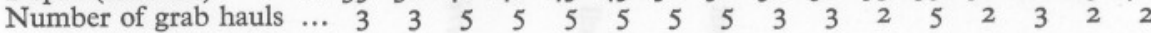
Species

Panthalis oerstedi Leanira tetragona

Mystides limbata

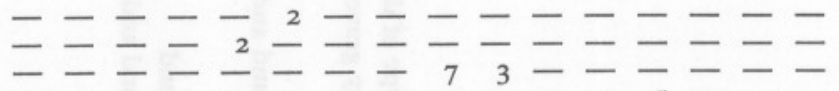

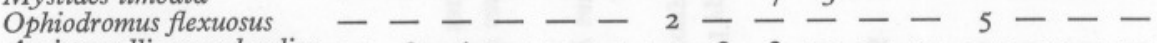

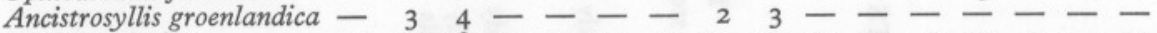

Nephthys incisa

Glycera convoluta

G. gigantea

G. rouxi

Goniada maculata

Eone nordmanni

Nematonereis unicornis

Lumbriconereis hibernica

L. gracilis

Spiophanes kroyeri

Polydora sp.

Prionospio malmgreni

Paraonis gracilis

Tharyx marioni

Diplocirrus glaucus

Scalibregma inflatum

$\begin{array}{llllllllllllllll}7 & 20 & 18 & \text { IO } & \text { IO } & \text { I2 } & 2 & \text { I2 } & 23 & \text { I0 } & \text { I5 } & 2 & \text { I5 } & 7 & - & \text { I5 }\end{array}$

Dasybranchus caducus

Ammotrypane aulogaster

Clymene gracilis

Rhodine loveni

Ampharete grubei

7 20 I8 I0 I0 I2 2 - 12 - 23 I0

$---\frac{1}{6}-\frac{2}{8}-\frac{2}{6}-\frac{5}{2}-\frac{-}{7}--$

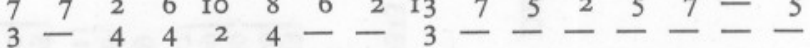

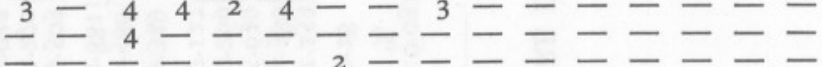

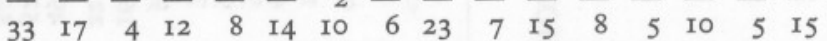

- - - - - $2-1---$

- - $\begin{array}{lllllllll}4 & 2 & 12 & 4 & 4 & 4\end{array}-10$

- - - - $-\frac{2}{2} \overline{2}-\overline{7}-\overline{5} \overline{6}-\overline{-}-\overline{10}$

$--1---1-232-7-$

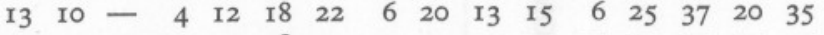

- - -

- 3642 10 $-233---10-$

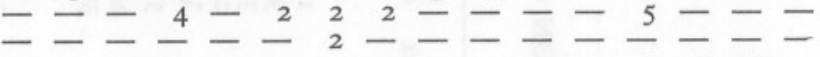

Pectinaria sp.

TABLE 3. POLYCHAET FAUNA OF MUDDY SAND

(As number per square metre.)

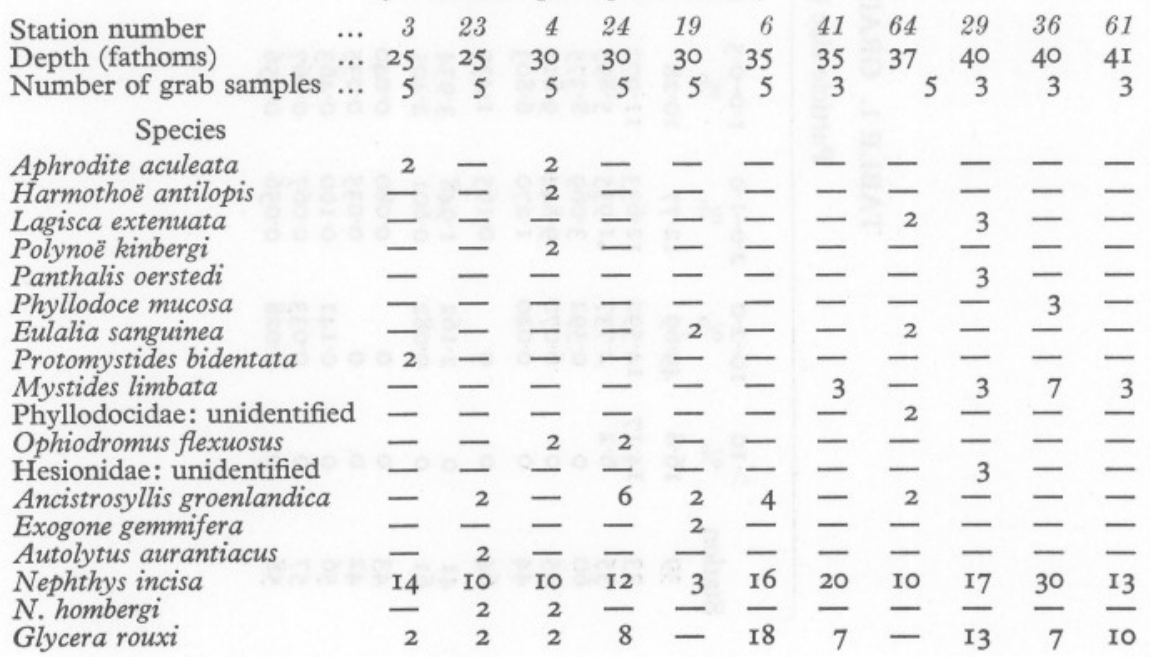


TABLE 3 (continued)

Station number

G. gigantea

G. convoluta

Goniada maculata

Eone nordmanni

Lumbriconereis hibernica

L. gracilis

Notocirrus scoticus

Drilonereis filum

Nerinides tridentata

Laonice cirrata

Spiophanes bombyx

S. kröyeri

Polydora flava

Prionospio malmgreni

$P$. steenstrupi

Aricidea branchiata

Paraonis lyra

$P$. gracilis

Chaetopterus variopedatus

Heterocirrus zetlandicus

Heterocirrus sp.

Chaetozone setosa

Tharyx marioni

Diplocirrus glaucus

Scalibregma inflatum

Notomastus latericeus

Dasybranchus caducus

Owenia fusiformis

Myriochele heeri

Ammotrypane aulogaster

Rhodine loveni

Clymene affinis

Clymene sp.

Leiochone clypeata

Amphicteis gunneri

Sabellides octocirrata

Pectinaria auricoma

P. koreni

Pista cristata

Thelepus cincinnatus

Polycirrus denticulatus

P. plumosus

Trichobranches glacialis

Terebellides stroemi

Sabella pavonina
Ampharete grubei

\begin{tabular}{|c|c|c|c|c|c|c|c|c|c|c|}
\hline 3 & 23 & 4 & 24 & 19 & 6 & 41 & 64 & 29 & 36 & 61 \\
\hline- & - & - & - & - & 2 & - & - & - & - & - \\
\hline - & - & - & - & - & - & - & - & - & 3 & - \\
\hline- & 6 & 6 & 2 & 6 & 2 & 3 & I4 & - & 3 & - \\
\hline - & - & - & - & - & 4 & - & - & - & 7 & - \\
\hline 4 & 4 & 2 & 14 & - & I4 & 7 & 2 & 3 & IO & 3 \\
\hline & 8 & 2 & 6 & 4 & 2 & 7 & 2 & & - & - \\
\hline- & 0 & 2 & 2 & 2 & - & - & 4 & - & - & - \\
\hline- & 3 & - & $?$ & - & 2 & - & $\overline{0}$ & - & - & - \\
\hline I2 & - & - & - & - & - & - & - & - & 3 & Z \\
\hline - & I0 & - & - & 4 & 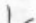 & - & - & - & 3 & - \\
\hline - & I4 & 12 & Io & 24 & & IO & 2 & - & 3 & 3 \\
\hline - & - & - & - & - & - & 3 & 2 & - & - & - \\
\hline - & I0 & - & 6 & 2 & 6 & - & 6 & - & IO & - \\
\hline - & - & 4 & - & - & - & - & - & - & - & - \\
\hline - & 2 & - & - & - & - & - & - & - & - & - \\
\hline- & - & - & - & - & - & 3 & - & - & - & - \\
\hline 一 & 一 & - & - & - & - & - & - & - & - & 3 \\
\hline- & - & - & - & - & - & - & 2 & - & - & - \\
\hline - & $\overline{8}$ & - & - & 4 & - & - & 8 & - & - & - \\
\hline 2 & & 6 & & 6 & - & E & - & - & - & - \\
\hline- & 2 & - & $\begin{array}{l}4 \\
6\end{array}$ & 2 & - & 10 & 3 & 70 & 3 & - \\
\hline 2 & 4 & 4 & - & IO & 1 & 3 & 8 & - & 2 & 43 \\
\hline- & - & - & - & - & - & - & 2 & - & 3 & - \\
\hline- & 6 & - & 6 & - & - & - & 2 & - & - & - \\
\hline- & - & - & - & - & - & - & - & - & - & 3 \\
\hline 26 & I92 & I6 & 2 & 386 & - & - & 12 & - & - & - \\
\hline 8 & I2 & 20 & 2 & 46 & - & 3 & 62 & - & 3 & - \\
\hline 2 & - & - & - & - & - & - & - & - & - & - \\
\hline - & - & - & - & 2 & - & - & - & - & - & - \\
\hline - & 2 & - & 2 & 8 & - & - & 12 & - & 6 & - \\
\hline - & 2 & - & 二 & - & - & - & - & - & - & - \\
\hline- & - & - & 2 & 6 & 二 & 二 & - & $\bar{z}$ & $\sqrt{2}$ & - \\
\hline 6 & 6 & 8 & 2 & 2 & 4 & - & - & & 2 & - \\
\hline- & - & - & - & 4 & - & - & - & - & - & - \\
\hline 8 & 8 & 4 & - & IO & - & - & - & - & 3 & - \\
\hline 2 & 6 & 2 & - & I4 & - & - & - & - & - & - \\
\hline- & 2 & - & - & - & 一 & - & - & - & - & - \\
\hline - & - & - & - & 2 & - & - & - & - & - & - \\
\hline- & 一 & 2 & - & - & 2 & - & - & - & - & 一 \\
\hline - & - & 2 & - & 6 & - & - & - & 3 & - & - \\
\hline- & I0 & IO & - & 6 & 2 & - & 2 & - & 7 & - \\
\hline 2 & IO & 8 & 2 & 2 & - & - & 4 & - & 7 & - \\
\hline - & - & - & - & 2 & - & - & - & - & - & - \\
\hline
\end{tabular}

\section{TABLE 4. POLYCHAET FAUNA OF MUDDY SAND MIXED WITH SHELL GRAVEL}

(Number per square metre or relative abundance.)

Station number

Depth (fathoms)

Dredge (D) or grab (G)

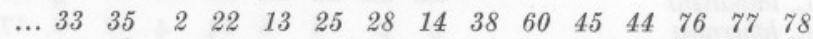

Number of samples

$\begin{array}{lllllllllllllll}\text {... I7 } & \text { I8 } & 20 & 20 & 20 & 25 & 29 & 30 & 30 & 3 I & 32 & 34 & 35 & 35 & 35\end{array}$

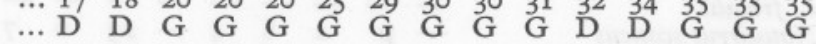

Species

Aphrodite aculeata

Lepidonotus squamatus

Harmothoë impar

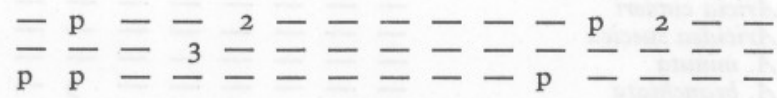

JOURN. MAR. BIOL. ASSOC. VOL. 36, 1957 
TABLE 4 (continued)

Station number

$H$. antilopis

$H$. haliaeti

$H$. longisetis

$H$. sp.

Lagisca extemuata

Sthenelais minor

Pholoë minuta

Phyllodoce mucosa

Eulalia bilineata

E. fucescens

E. sanguinea

E. macroceros

Notophyllum foliosum

Eteone longa

Protomystides bidentata

Mystides limbata

Phyllodocidae: unidentified

Podarke pallida

Castalia punctata

Ancistrosyllis groenlandica

Syllis variegata

$S$. armillaris

$S$. cornuta

Eusyllis blomstrandi

Odontosyllis fulgurans

O. gibba

Eurysyllis tuberculata

Exogone gemmifera

$E$. verugera

$E$. hebes

Sphaerosyllis hystrix

Autolytus aurantiacus

Nereis pelagica

Nephthys incisa

$N$. hombergi

N. rubella

Ephesia gracilis

E. periphatus

Glycera rouxi

G. gigantea

$G$. convoluta

G. lapidum

G. capitata

Goniada maculata

$G$. norvegica

Eone nordmanni

Eunice harassi

Onuphis conchylega

Nematonereis unicornis

Lumbriconereis gracilis

L. latreilli

L. impatiens

L. hibernica

L. fragilis

Notocirrus scoticus

Drilonereis filum

Eunicidae: unidentified

Aricia cuvieri

Aricidea suecica

A. minuta

A. branchiata

Laonice cirrata $\begin{array}{lllllllllllllll}\text {.. } 33 & 35 & 2 & 22 & 13 & 25 & 28 & 14 & 38 & 60 & 45 & 44 & 76 & 77 & 78\end{array}$

- 6 - $-12-7$ - $-1-2$

$-\overline{\mathrm{p}}-\overline{3}-\overline{2}-\overline{2}-\overline{-}-\overline{-}-\overline{-}-\overline{1}$

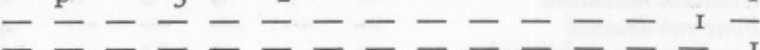

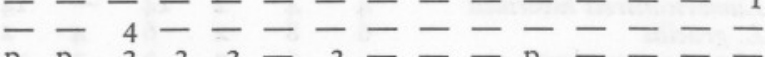

p $\frac{\mathrm{p}}{2}-\frac{2}{2}-\frac{3}{2}-\overline{\mathrm{p}}-\overline{-}-\overline{-}$

$\mathrm{p}---12------$

$\mathrm{p}$ p -----------

$\mathrm{p}-2--2-----\ldots-2$

- $-4-\overline{4}-\overline{-}-\overline{-}-\overline{\mathrm{p}}-\overline{-}-\overline{-}$

p p $\quad 2--------$

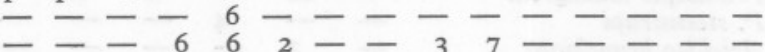

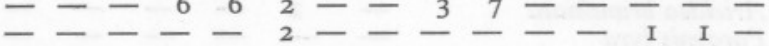

$\mathrm{p}----------1$

$\mathrm{p} p-5-2-------$

- $\mathrm{p}-\overline{\mathrm{p}}-\overline{2}-\mathbf{2}-\mathbf{3}-\overline{-}-\overline{-}-\overline{-}$

c $-4-28-----\mathrm{p}---$

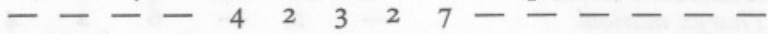

$-\mathrm{p}-3-1------$

$\mathrm{p}=- \pm-E-E-E-E-$

$\mathrm{p}-------3---$

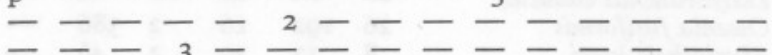

$\mathrm{p}--3---------$

$\mathrm{p}---2------$

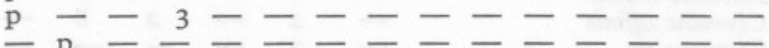

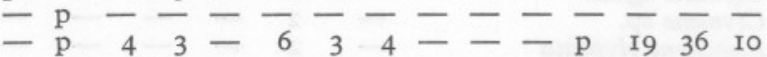

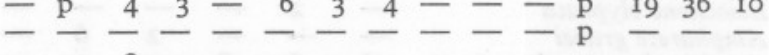

$\overline{\mathrm{p}}-\mathrm{p}-\overline{-}-\overline{-}-\overline{-}-\overline{-}-\overline{-}-\overline{-}$

$\mathrm{p}-----------$

$-\mathrm{p}-5 \mathrm{I} 2-272 \mathrm{I} 3-\mathrm{p} p \mathrm{p}^{2} 3$

- - - - $4-1-7-1$ - 2 I

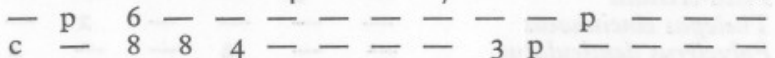

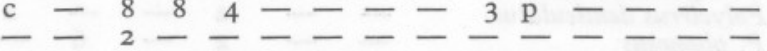

$-\mathrm{p}-36-27-7-\mathrm{p}$ c 6229

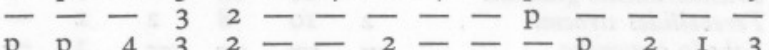

$\mathrm{p} \quad \mathrm{p}-2-3---1 \mathrm{p}--\frac{3}{1}$

$\mathrm{p} p-3-2327-1$

c c $43462-323$ p - - - -

$\begin{array}{lllllllllllllll}\text { c } & c & 4 & 20 & \text { I2 } & 4 & \text { I3 } & \text { I0 } & 33 & 7 & - & \text { p } & 9 & \text { I } & 6\end{array}$

p - - - - - $-3-7-7---$

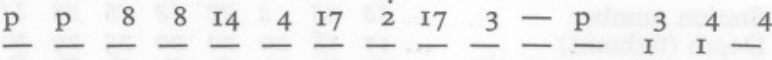

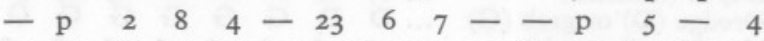

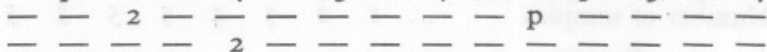

$-----1-3-\mathrm{p}-\mathrm{-}-\mathrm{I}-$

E- - - E - - - - - - - I - -

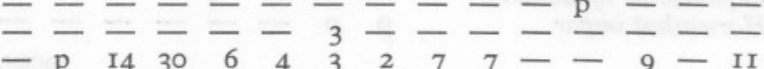


TABLE 4 (continued)

Station number

Aonides paucibranchiata Spiophanes bombyx

$S$. kröyeri

Polydora flava

$P$. ciliata

$P$. caulleryi

Polydora sp.

Prionospio malmgreni

$P$. steenstrupi

Poecilochaetus serpens

Phyllochaetopterus socialis

Heterocirrus zetlandicus

H. caput-esocis

Tharyx marioni

Chaetozone setosa

Dodecaceria concharum

Macrochaeta clavicornis

Zeppelinia dentata

Diplocirrus glaucus

Scalibregma inflatum

Notomastus latericeus

Owenia fusiformis

Myriochele heeri

Ammotrypane aulogaster

Clymene affinis

C. robusta

Clymene sp.

Nicomache lumbricalis

Praxillura longissima

Leiochone clypeata

Ampharete grubei

Amphicteis gunneri

Anobothrus gracilis

Sabellides octocirrata

Melinna cristata

M. palmata

Sabellaria spinulosa

Pectinaria auricoma

$P$. koreni

Amphitrite gracilis

Phisidia aurea

Pista cristata

Thelepus cincinnatus

Polycirrus denticulatus

$P$. plumosus

Amaea trilobata

Lysilla loveni

Trichobranchus glacialis

Terebellides stroemi

Terebellidae: unidentified

Sabella pavonina

Dasychone bombyx

Potamilla reniformis

Chone suspecta

Euchone rubrocincta

Myxicola infundibulum

Serpula vermicularis

Hydroides norvegica

Pomatoceros triqueter

Spirorbis spirillum $\begin{array}{lllllllllllllll}\text {... } 33 & 35 & 2 & 22 & 13 & 25 & 28 & 14 & 38 & 60 & 45 & 44 & 76 & 77 & 78\end{array}$

$\mathrm{p}-4-4------$

- - - - 4 2-8- - - -

$---8-623-3-\mathrm{p}-4$ I 5

$\mathrm{p} p--2---1-1-1$

- - - - I4 - - - - - - - -

$--3--------$

- - $2----------$

$----1-7-2-1$

$-2-2-2-2$

- $\mathrm{p}-\mathrm{3}-\overline{-}-\overline{-}-\overline{-}-\mathrm{p}-\mathrm{I}-\mathrm{I}-$

c c $-83243-37$ p p I - -

$\mathrm{p} p-\frac{\mathrm{p}}{8} 2 \frac{2}{6}-\frac{3}{3}----$

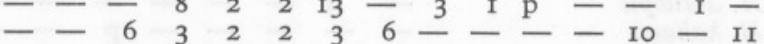

- - $2---------$

$\mathrm{p}----------$

$---12-------$

$--1-2-23-1-$ I 77

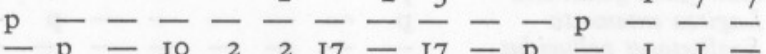

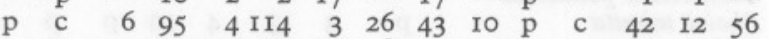

$\begin{array}{lllllllllllll}-\mathrm{p} & - & \mathrm{I} 3 & 2 & 24 & 40 & 8 & 3 & - & -\mathrm{p} & 4 & 6 & 42\end{array}$

$\mathrm{p}--12-1---1-12$

- $-2-2---1---$

$\mathrm{p}--\frac{3}{-}-\frac{3}{-}-1- \pm=$

- p - - - 2- - - - - - -

$-\mathrm{p}---------$

- - - - ${ }_{6}^{4}--\overline{7}--\overline{3}----$

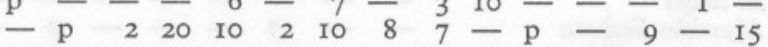

- $\mathrm{p}-----------$

$--1-2--4-----$

$-\mathrm{p}----\mathrm{z}^{2}-\mathrm{p}---$

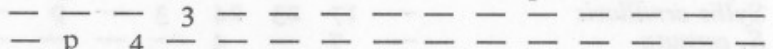

- $\mathrm{p} 4-26-34$ 10 2 - $-\mathrm{c} 23$ 10 16

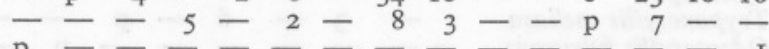

$\mathrm{p}--------1$

$\mathrm{p}--4-23--3 \mathrm{p}---$

$-\mathrm{p}-20-2--7-\mathrm{p}---$

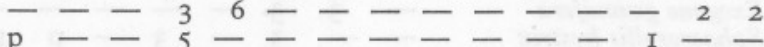

$---2-2---1-2-$

- - - - - - - - - p - - -

$-7-32--------$

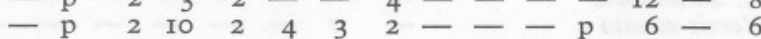

$-1---1-7 \mathrm{p}-2 \mathrm{I}-$

$----20--\mathrm{I} 2--\mathrm{p}---$

$----1-3---1-$

$\mathrm{p}---$ I0 -------

$\mathrm{p}---2-------$

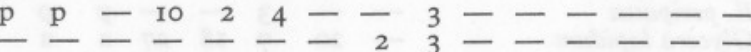

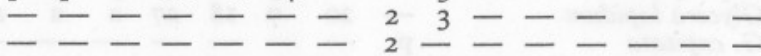

p -\begin{tabular}{llllllllllll}
\hline & I5 & 22 & 2 & 3 & 2 & I3 & 20 & p & p & - & -
\end{tabular}

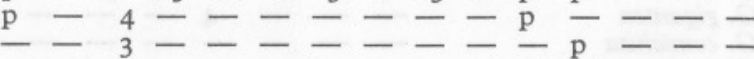

$\mathrm{p}=$ present $\mathrm{c}=$ common. 
TABLE 5. POLYCHAET FAUNA OF FINE GRAVELS

(Expressed as numbers per square metre, or relative abundance.)

Fine shell gravel Fine stony gravel Coralline gravel

$\begin{array}{llllllllllllllllllllllllllll}\text { Station number } & \ldots & 71 & 20 & 21 & 26 & 27 & 75 & 10 & 11 & 39 & 34 & 12 & 5 & 12 & 30\end{array}$

$\begin{array}{llllllllllllllll}\text { Depth (fathoms) } & \ldots & \text { I8 } & 20 & 20 & 25 & 30 & 6 & 9 & \text { 10 } & \text { I0 } & \text { 15 } & \text { I5 } & \text { I5 } & \text { 15 } & \text { I5 } \\ \text { Dredge (D) or Grab (G) ... } & \text { D } & \text { G } & \text { G } & \text { G } & \text { G } & \text { D } & \text { D } & \text { D } & \text { D } & \text { D } & \text { G } & G & G & G\end{array}$

$\begin{array}{lllllllllllllll}\text { Number of hauls } & \text { I } & 3 & 3 & 5 & 3 & \text { I } & \text { I } & \text { I } & \text { I } & \text { I } & 4 & 5 & 5 & \text { I }\end{array}$

Species

Aphrodite aculeata

Malmgrenia castanea

Gattyana cirrosa

Lepidonotus squamatus

Harmothoë impar

$H$. antilopis

$H$. haliaeti

$H$. longisetis

H. lunulata

Harmothoë sp.

Halosydna gelatinosa

Lagisca extenuata

Scalisetosus pellucidus

Pholoë minuta

Pisione remota

Phyllodoce kosteriensis

Notophyllum foliosum

Eulalia viridis

E. bilineata

E. sanguinea

Eulalia sp.

Eteone foliosa

E. longa

Mystides limbata

Podarke pallida

Castalia punctata

Kefersteinia cirrata

Syllis armillaris

S. cornuta

Syllis sp.

Trypanosyllis coeliaca

Odontosyllis fulgurans

Eusyllis blomstrandi

Eurysyllis tuberculata

$\mathrm{p}------\mathrm{p}---$

Exogone gemmifera

Sphaerosyllis hystrix

$S$. bulbosa

Autolytus rubropunctatus

A. prolifer

A. aurantiacus

Nereis zonata

$N$. pelagica

Platynereis dumerilii

Nephthys incisa

N. rubella

Ephesia gracilis

E. peripatus

Glycera lapidum

G. capitata

$G$. rouxi

G. gigantea

$G$. convoluta

Goniada maculata

Eone nordmanni

\begin{tabular}{|c|c|c|c|c|c|c|c|c|c|c|c|c|c|}
\hline & - & - & - & - & - & - & - & - & $\mathrm{p}$ & - & - & - & \\
\hline & - & - & 2 & - & - & - & - & - & - & - & - & 2 & - \\
\hline & - & - & - & - & - & - & - & - & $\mathrm{p}$ & - & 2 & - & - \\
\hline & - & - & - & - & - & $\mathrm{p}$ & - & - & p & - & - & - & - \\
\hline & 7 & 7 & - & - & - & - & - & - & - & - & - & - & - \\
\hline & 3 & - & - & - & $\bar{n}$ & - & - & - & - & - & 2 & 4 & 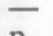 \\
\hline & - & - & - & - & p & - & - & - & - & - & - & - & p \\
\hline & & & & & & & - & & & - & - & - & $\mathrm{n}$ \\
\hline & & 2 & - & - & - & & & & & 3 & 2 & 2 & \\
\hline & - & - & - & - & - & & - & & & - & - & - & 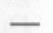 \\
\hline & - & - & - & - & - & $\mathrm{p}$ & - & - & & - & - & - & $\mathrm{p}$ \\
\hline & - & - & - & - & - & - & - & - & & - & - & - & - \\
\hline & 3 & 3 & 4 & I0 & p & p & - & - & & 5 & 6 & I0 & c \\
\hline & - & - & - & - & & & p & - & & - & - & 2 & - \\
\hline & - & - & - & - & - & - & - & - & $\mathrm{p}$ & - & - & - & - \\
\hline & - & 3 & 6 & - & - & - & - & - & 一 & - & - & - & - \\
\hline & - & - & 4 & - & - & - & - & - & - & - & - & - & p \\
\hline & - & - & 6 & - & - & - & - & - & - & - & - & - & \\
\hline & 23 & 3 & 2 & - & - & $\mathrm{p}$ & - & - & p & - & - & - & 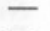 \\
\hline & - & - & - & 3 & - & - & p & - & - & - & - & - & \\
\hline & 3 & - & - & 3 & - & - & - & - & - & - & - & - & \\
\hline & - & $\bar{\pi}$ & - & - & - & - & - & & - & - & - & - & 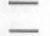 \\
\hline & Z & -7 & $\overline{ }$ & - & 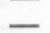 & $\mathrm{p}$ & 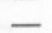 & 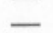 & & 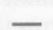 & . & . & \\
\hline & 7 & 63 & I0 & - & - & - & - & - & & - & - & - & \\
\hline & - & - & - & - & - & $\mathrm{p}$ & - & - & & - & - & - & p \\
\hline & I7 & 23 & 24 & 3 & - & p & - & - & & - & - & 2 & \\
\hline & 7 & - & 4 & - & - & - & - & - & & - & 2 & 2 & \\
\hline & - & - & 6 & - & - & - & - & & - & - & - & - & - \\
\hline & 3 & - & 6 & 一 & $\mathrm{p}$ & - & - & - & - & - & - & - & - \\
\hline & - & - & - & - & - & $\mathrm{p}$ & - & - & C & - & 6 & - & - \\
\hline & 13 & - & - & - & - & - & - & - & - & - & - & - & $\mathrm{p}$ \\
\hline & I3 & 3 & - & - & - & - & - & - & - & - & - & - & - \\
\hline & 3 & 3 & - & - & - & - & - & - & - & - & - & - & - \\
\hline & - & 3 & - & 3 & - & p & p & - & - & - & - & - & - \\
\hline & - & - & 2 & - & - & p & - & - & - & - & - & - & - \\
\hline & - & 3 & - & - & - & - & - & - & - & - & - & - & 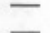 \\
\hline & 3 & - & 2 & 3 & - & - & & & & - & - & & \\
\hline & 7 & 二 & - & - & - & - & & & - & - & - & - & \\
\hline & - & - & - & - & - & - & - & - & - & - & - & - & \\
\hline & - & - & - & - & - & - & - & - & - & - & - & - & \\
\hline & - & - & - & - & - & - & - & - & p & - & & & \\
\hline & - & - & - & - & - & - & - & & - & - & 2 & - & \\
\hline- & 3 & - & - & - & - & - & - & - & p & 3 & 2 & - & c \\
\hline & - & 3 & - & - & p & D & & & & - & - & 2 & p \\
\hline & 20 & 7 & I8 & 27 & a & d & a & & $\mathrm{p}$ & IO & 32 & 34 & a \\
\hline & - & - & - & - & - & - & - & - & - & - & - & - & - \\
\hline & - & - & - & 3 & p & - & - & - & $\mathrm{p}$ & 3 & 2 & 6 & p \\
\hline & - & - & 4 & - & - & - & - & - & - & - & 2 & - & $\mathrm{p}$ \\
\hline & - & - & - & - & - & - & & & c & - & - & - & \\
\hline & - & - & - & 3 & - & - & & & - & - & 2 & - & $\mathrm{p}$ \\
\hline & & 3 & 4 & & - & - & & & & - & 4 & 2 & \\
\hline
\end{tabular}


TABLE 5 (continued)

Station number

Eunice harassi

Onuphis conchylega

Nematonereis unicornis

Lumbriconereis gracilis

L. fragilis

L. hibernica

Drilonereis filum

Staurocephalus neglectus

Aricia cuvieri

Laonice cirrata

Aonides paucibranchiata

Spiophanes bombyx

Polydora ciliata

P. flava

$P$. caulleryi

Aricidea jeffreysi

A. branchiata

Paraonis lyra

Heterocirrus zetlandicus

H. caput-esocis

$H$. bioculatus

Tharyx marioni

Dodecaceria concharum

Macrochaeta clavicornis

Stylarioides plumosa

Diplocirrus glaucus

Flabelligera affinis

Scalibregma inflatum

Notomastus latericeus

Capitomastus minimus

Maldane sarsi

Clymene affinis

Leiochone clypeata

Nicomache trispinata

Maldanidae: unidentified

Owenia fusiformis

Myriochele heeri

Pectinaria auricoma

P. koreni

Sabellaria spinulosa

Ampharete grubei

Anobothrus gracilis

Amphicteis gunneri

Melinna palmata

M. cristata

Phisidia aurea

Pista cristata

Polymnia nebulosa

Nicolea zostericola

Thelepus cincinnatus

Polycirrus denticulatus

Trichobranchus glacialis

Terebellides stroem $i$

Lysilla loveni

Potamilla reniformis

Fabricia sabella

fasminiera caudata

Chone suspecta

Euchone rubrocincta

Hydroides norvegica

Pomatoceros triqueter

Spirorbis spirillum.

\begin{tabular}{|c|c|c|c|c|c|c|c|c|c|c|c|c|c|}
\hline 71 & 20 & 21 & 26 & 27 & 75 & 10 & 11 & 39 & 34 & $I$ & 5 & 12 & 30 \\
\hline $\mathrm{p}$ & - & - & 2 & - & - & - & - & - & - & - & - & - & - \\
\hline $\mathrm{p}$ & - & - & - & - & - & - & - & - & - & - & - & - & - \\
\hline & Io & 20 & I4 & Io & - & $\mathrm{p}$ & - & - & $\mathrm{p}$ & 35 & I8 & Io & p \\
\hline- & I0 & - & 4 & I3 & $\mathrm{p}$ & $\mathrm{p}$ & - & - & c & 35 & 96 & 40 & c \\
\hline- & - & - & 2 & - & $\mathrm{p}$ & $\mathrm{p}$ & - & - & - & - & 2 & 2 & c \\
\hline- & - & - & - & 3 & - & - & - & - & $\mathrm{p}$ & - & - & - & - \\
\hline & - & - & - & - & - & - & - & - & - & - & - & 2 & \\
\hline & - & - & - & - & $\mathrm{p}$ & $\mathrm{p}$ & $\mathrm{p}$ & - & - & - & - & - & - \\
\hline$\overline{7}$ & 3 & - & $\overline{21}$ & $\bar{z}$ & - & - & - & - & - & $\bar{z}$ & $\bar{x}$ & 4 & 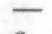 \\
\hline $\mathrm{p}$ & 7 & 7 & 34 & I7 & $\mathrm{p}$ & c & - & $\mathrm{p}$ & p & I3 & I0 & 22 & c \\
\hline & 30 & 3 & 42 & 7 & c & c & c & c & - & - & - & 2 & p \\
\hline- & - & - & - & - & - & - & - & $\mathrm{p}$ & $\mathrm{p}$ & - & - & - & - \\
\hline- & - & 7 & - & - & - & - & - & - & - & - & - & - & - \\
\hline- & 3 & - & 2 & - & - & - & - & - & - & - & - & - & - \\
\hline - & - & - & 2 & - & - & p & - & - & - & - & - & - & - \\
\hline- & - & - & 4 & 一 & - & - & - & - & - & 3 & - & - & - \\
\hline - & - & - & - & - & - & - & - & - & - & - & - & 2 & - \\
\hline - & - & $\overline{5}$ & 2 & - & - & - & - & - & - & - & - & 6 & \\
\hline- & - & 26 & 4 & - & - & - & - & - & c & - & 4 & - & - \\
\hline- & - & 3 & 4 & - & - & - & - & - & - & - & - & - & - \\
\hline- & - & - & - & - & - & - & - & - & - & 2 & - & - & - \\
\hline & - & 30 & 2 & 3 & Z & - & - & Z & $\mathrm{p}$ & - & - & - & - \\
\hline 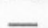 & & 20 & - & 二 & - & - & - & - & - & - & - & - & - \\
\hline & 3 & & & & & p & - & - & - & - & - & IO & $\mathrm{p}$ \\
\hline - & - & - & 2 & 3 & - & - & - & - & - & - & 一 & - & - \\
\hline- & 二 & - & - & Z & - & - & - & - & - & 3 & - & - & - \\
\hline Z & - & - & Z & - & - & 二 & $\bar{z}$ & $\bar{E}$ & $\bar{n}$ & - & - & - & $\mathrm{p}$ \\
\hline- & - & - & - & - & $\mathrm{p}$ & & & - & $\underline{p}$ & - & 2 & 2 & p \\
\hline- & 3 & - & - & - & $\mathrm{c}$ & a & C & - & a & 40 & 48 & 50 & $\underline{p}$ \\
\hline- & - & 7 & - & - & - & - & - & - & - & - & - & - & - \\
\hline- & - & - & - & 6 & - & $\mathrm{p}$ & - & - & c & - & 4 & - & - \\
\hline - & - & - & - & - & $\mathrm{p}$ & p & - & - & - & - & - & - & - \\
\hline - & - & - & - & - & - & - & - & - & $\mathrm{p}$ & - & - & - & - \\
\hline- & 3 & - & - & - & - & - & - & - & $\mathrm{p}$ & - & - & - & - \\
\hline p & - & 3 & 6 & 3 & - & - & - & - & a & - & 2 & - & - \\
\hline 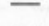 & - & - & - & - & - & - & - & - & $\mathrm{p}$ & - & - & - & - \\
\hline - & - & - & - & - & - & - & - & - & $\mathrm{p}$ & 3 & 2 & - & - \\
\hline 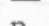 & $\bar{z}$ & E & $\overline{2}$ & $\overline{3}$ & - & 二 & - & $\bar{z}$ & Z & 3 & 二 & - & - \\
\hline & - & - & - & $\begin{array}{l}3 \\
2\end{array}$ & - & - & - & - & $\mathrm{n}$ & $\overline{-}$ & Z & - & - \\
\hline 1 & - & - & - & - & - & - & - & - & p & - & - & - & - \\
\hline p & - & - & - & - & - & - & - & - & - & - & - & 2 & \\
\hline - & - & - & - & - & - & - & - & - & - & 8 & - & - & - \\
\hline - & - & - & - & - & - & - & - & - & - & - & - & - & $\mathrm{p}$ \\
\hline- & - & 3 & - & - & - & - & - & - & - & - & - & - & - \\
\hline - & - & - & 2 & - & a & $\mathrm{a}$ & c & a & $\mathrm{p}$ & 3 & I0 & 22 & c \\
\hline p & - & - & - & - & - & - & - & - & - & - & - & - & - \\
\hline- & 3 & - & - & - & - & - & - & - & - & - & - & - & - \\
\hline- & - & - & 12 & - & - & - & - & - & - & - & - & - & $\mathrm{p}$ \\
\hline & 13 & 10 & 2 & 10 & $\mathrm{p}$ & p & - & - & $\mathrm{p}$ & - & 2 & 4 & $\mathrm{p}$ \\
\hline $\mathbf{p}$ & 3 & - & $\bar{z}$ & $\bar{z}$ & - & p & - & 二 & p & - & 2 & 2 & $\bar{x}$ \\
\hline & & - & - & - & - & - & - & - & - & -3 & 10 & - & \\
\hline - & - & 27 & 8 & 3 & - & - & - & - & $p$ & - & - & - & - \\
\hline- & - & - & - & 3 & - & - & - & - & - & - & - & - & - \\
\hline- & - & - & 2 & - & - & - & - & - & - & - & - & - & - \\
\hline - & 7 & 3 & 38 & - & $\mathrm{p}$ & $\mathrm{p}$ & - & - & - & 3 & - & 2 & p \\
\hline - & - & - & - & 3 & - & - & - & - & - & - & - & 2 & - \\
\hline - & I7 & 57 & 26 & 3 & - & - & - & - & p & - & - & - & p \\
\hline- & 30 & 3 & $3^{8}$ & - & - & $\mathrm{p}$ & - & - & a & - & - & - & - \\
\hline- & 170 & 33 & & - & - & - & - & - & - & - & - & - & - \\
\hline
\end{tabular}

$\mathrm{p}=$ present $\mathrm{c}=$ common $\mathrm{a}=$ abundant. 
TABLE 6. POLYCHAET FAUNA OF COARSE GRAVELS

Shell gravel

Stones

Station number

Depth (fathoms)

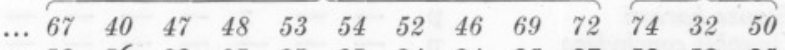

Species

Hermione hystrix

Gattyana cirrosa

Lepidonotus squamatus

Harmothoë impar

H. haliaeti

$H$. reticulata

Halosydna gelatinosa

Lagisca extemuata

Polynoë scolopendrina

Scalisetosus assimilis

S. pellucidus

Pholoë minuta

Phyllodoce laminosa

Eulalia viridis

E. fucescens

E. macroceros

Castalia punctata

Kefersteinia cirrata

Syllis armillaris

S. variegata

Trypanosyllis coeliaca

Eusyllis blomstrandi

Exogone gemmifera

Autolytus pictus

A. rubropunctatus

A. longeferiens

A. aurantiacus

Autolytus sp.

Myrianida pinnigera

Nereis pelagica

Platynereis dumerilii

Nephthys incisa

Ephesia gracilis

Glycera lapidum

Goniada maculata

Eone nordmanni

Lumbriconereis fragilis

Polydora caeca

Chaetopterus variopedatus

Heterocirrus zetlandicus

Flabelligera affinis

Clymene robusta

Owenia fusiformis

Petta pusilla

Pectinaria auricoma

Sabellaria spinulosa

Polymnia nebulosa

Pista cristata

Polycirrus denticulatus

Potamilla reniformis

Dasychone bombyx

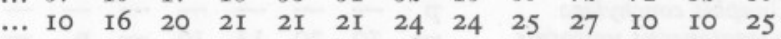

Sabellidae: unidentified

Serpula vermicularis

Hydroides norvegica

Pomatoceros triqueter

Protula tubularia

Filograna implexa

Spirorbis sp.

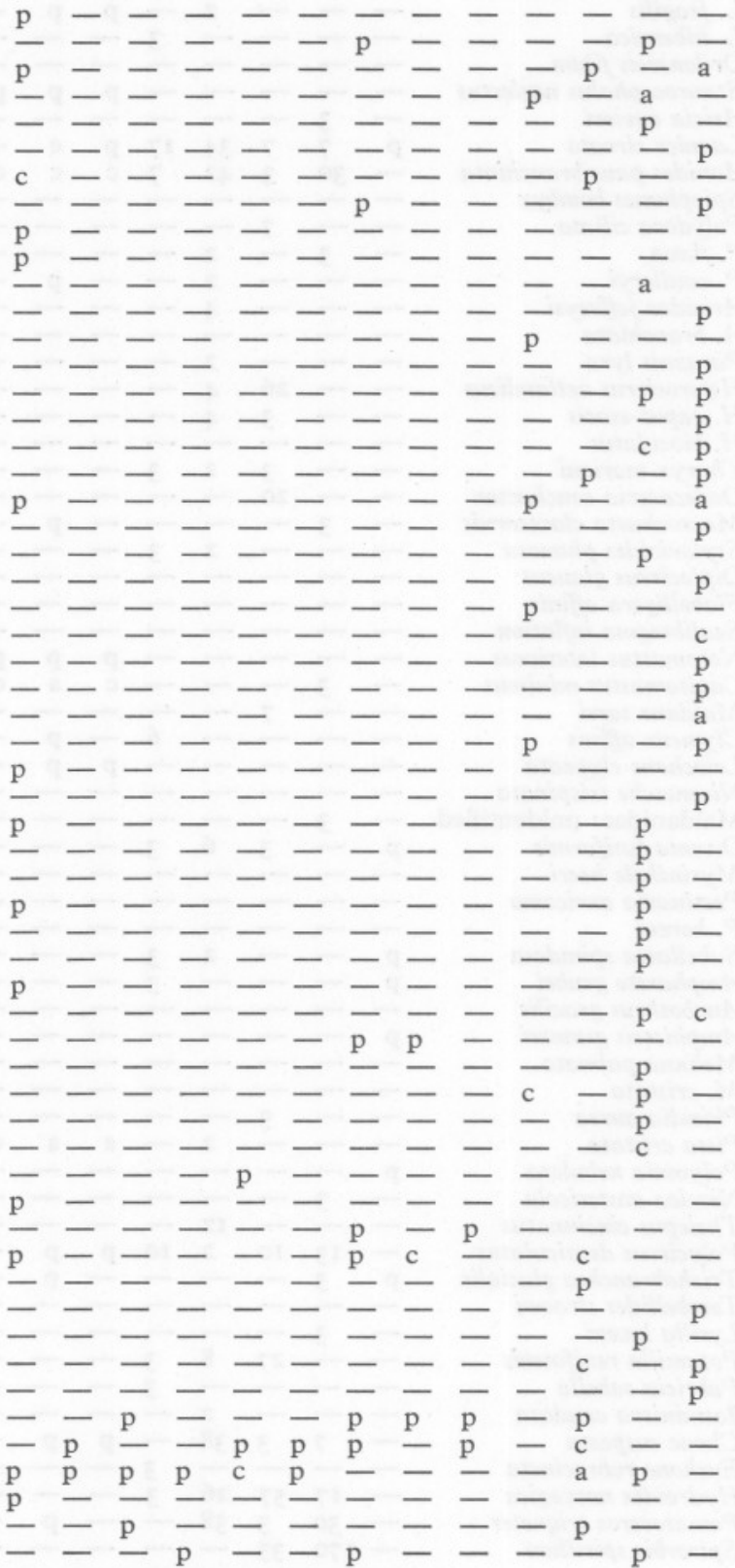

$\mathrm{p}=$ present $\mathrm{c}=$ common $\mathrm{a}=$ abundant. 
TABLE 7. POLYCHAETA BORING OR INHABITING CREVICES IN EMPTY SHELLS OR SERPULID TUBES (RELATIVE ABUNDANCE)

Shell

Station number

Depth (fathoms)

\begin{tabular}{|c|c|c|c|c|c|}
\hline Ostrea & Modiolus & Glycimeris & \multicolumn{3}{|c|}{ Serpulid tubes } \\
\hline 54 & 52 & 53 & 68 & 48 & 46 \\
\hline $\begin{array}{lll}16 & 2 I & 2 I\end{array}$ & 24 & 24 & IO & $2 \mathrm{I}$ & 2 \\
\hline
\end{tabular}

Pholoë minuta

Species

Eulalia viridis

E. viridis var. aurea

E. bilineata

E. sanguinea

E. fucescens

E. pusilla

E. macroceros

Notophyllum foliosum

Castalia punctata

Syllis armillaris

S. amica

$S$. variegata

Trypanosyllis coeliaca

Odontosyllis fulgurans

Eusyllis blomstrandi

Exogone gemmifera

Autolytus rubropunctatus

A. longeferiens

A. aurantiacus

Nereis zonata

Nematonereis unicornis

Polydora ciliata

P. caeca

P. flava

P. giardi

Heterocirrus zetlandicus

Dodecaceria concharum

Lumbriclymene minor

Polycirrus denticulatus

Potamilla torelli

$P$. reniformis

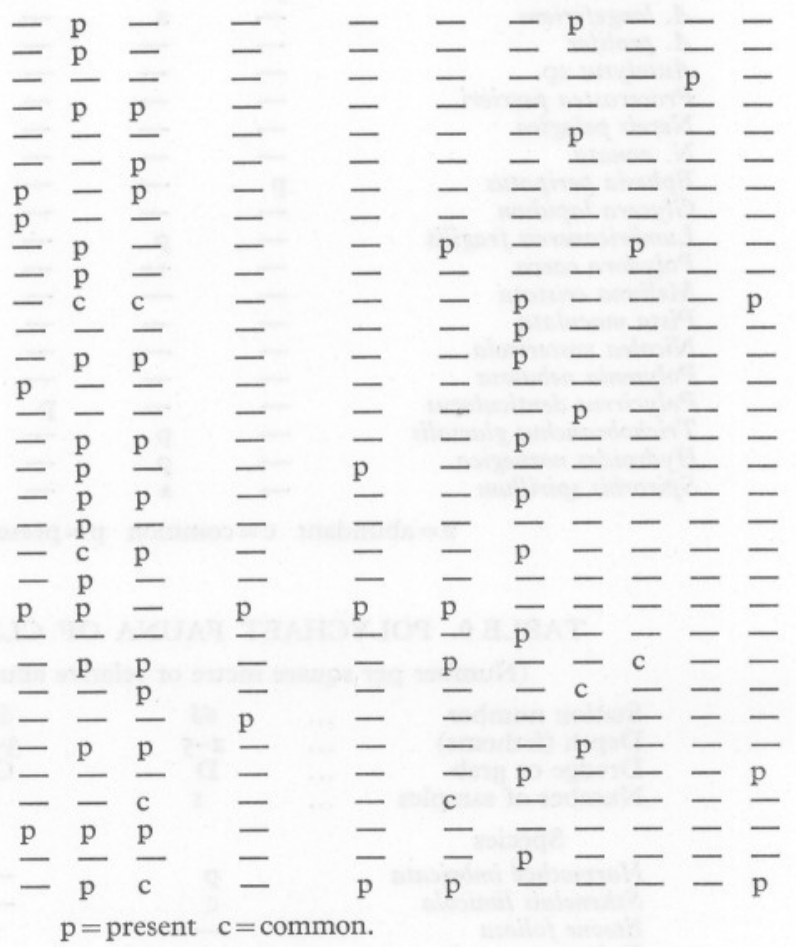

TABLE 8. POLYCHAET FAUNA OF HYDROIDS

(Relative abundance.)

Station number

Depth (fathoms)

\section{Species}

Lepidonotus squamatus

Harmothoë impar

Halosydna gelatinosa

Lagisca extenuata

Eulalia bilineata

E. fucescens

E. pusilla

Notophyllum foliosum

Mystides limbata.

Castalia punctata

Syllis armillaris

S. variegata $\begin{array}{lllllll}\ldots & 47 & 48 & 49 & 53 & 52 & 46 \\ \ldots & 20 & 2 \text { I } & \text { 2I } & \text { 2I } & 24 & 24\end{array}$

\begin{tabular}{|c|c|c|c|}
\hline- & - & $\mathrm{p}$ & $\mathrm{p}$ \\
\hline - & $\overline{-}$ & $\mathrm{p}$ & p \\
\hline 二 & $\overline{\mathrm{p}}$ & $\underline{p}$ & $\bar{p}$ \\
\hline - & - & $\mathrm{p}$ & - \\
\hline 二 & 二 & $\mathrm{p}$ & 二 \\
\hline - & - & - & - \\
\hline - & - & - & - \\
\hline $\bar{p}$ & $\overline{\mathrm{p}}$ & $\begin{array}{l}\mathrm{p} \\
\mathrm{a}\end{array}$ & $\underline{\mathrm{p}}$ \\
\hline & & 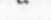 & \\
\hline
\end{tabular}


TABLE 8 (continued)

Station number

Eusyllis blomstrandi

Trypanosyllis zebra

Exogone gemmifera

Autolytus pictus

A. rubropunctatus

A. aurantiacus

$A$. longeferiens

A. prolifer

Autolytus sp.

Procerastea perrieri

Nereis pelagica

N. zonata

Ephesia peripatus

Glycera lapidum

Lumbriconereis fragilis

Polydora caeca

Melinna cristata

Pista maculata

Nicolea zostericola

Polymnia nebulosa

Polycirrus denticulatus

Trichobranchus glacialis

Hydroides norvegica

Spirorbis spirillum

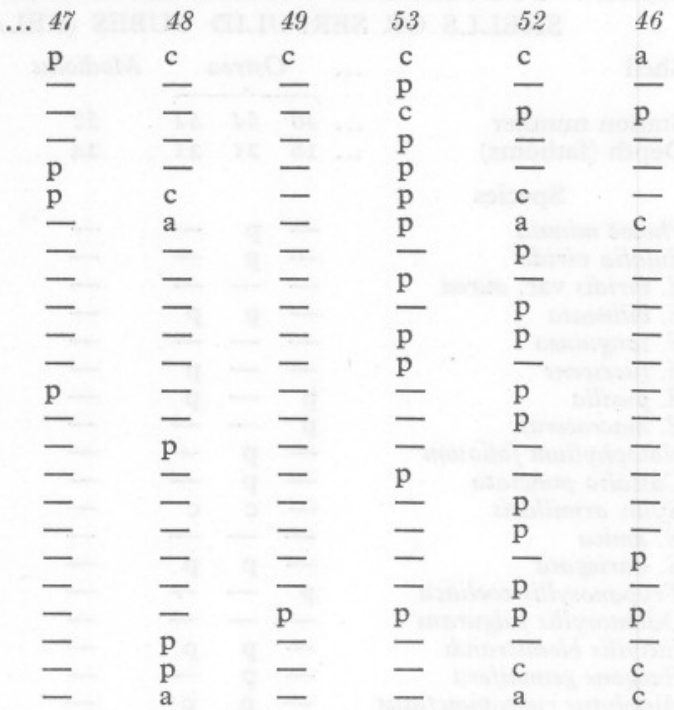

$\mathrm{a}=$ abundant $\mathrm{c}=$ common $\mathrm{p}=$ present .

\section{TABLE 9. POLYCHAET FAUNA OF CLEAN SAND}

(Number per square metre or relative abundance.)

Station number

Depth (fathoms)

Dredge or grab

Number of samples

$$
\begin{array}{cc}
\ldots & 65 \\
\ldots & 2-5 \\
\ldots & \text { D } \\
\ldots & \text { I }
\end{array}
$$

5

Species

Harmothoë imbricata

Sthenelais limicola

Eteone foliosa

E. longa

Mystides limbata

Kefersteinia cirrata

Exogone verugera

Nereis pelagica

Platynereis dumerilii

Nephthys cirrosa

Glycera convoluta

G. gigantea

$G$. rouxi

Goniada maculata

Eone nordmanni

Nematonereis unicornis

Scoloplos armiger

Spiophanes bombyx

Polydora caulleryi

Magelona papillicornis

Chaetozone setosa

Heterocirrus zetlandicus

Capitella capitata

Clymene oerstedii

Owenia fusiformis

Pista cristata

Polycirrus denticulatus

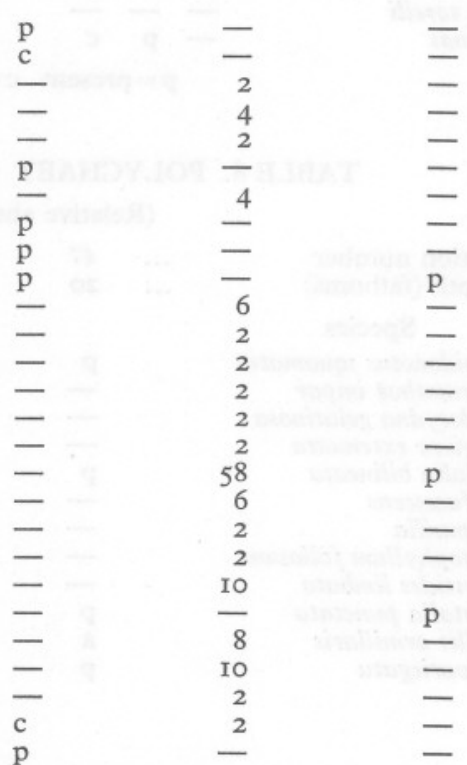

$\mathrm{c}=$ common $\mathrm{p}=$ present. 
TABLE 10. COMPOSITION OF THE MACROFAUNA OF VARIOUS DEPOSITS

Polychaeta

\begin{tabular}{|c|c|c|c|c|c|}
\hline \multirow[b]{2}{*}{ Habitat } & \multicolumn{5}{|c|}{ Percentage of total population per station } \\
\hline & $\begin{array}{l}\text { Polychaeta } \\
\text { Mean }\end{array}$ & $\begin{array}{l}\text { Crustacea } \\
\text { Mean }\end{array}$ & $\begin{array}{c}\text { Mollusca } \\
\text { Mean }\end{array}$ & $\begin{array}{c}\text { Echinodermata } \\
\text { Mean }\end{array}$ & $\begin{array}{l}\text { Others } \\
\text { Mean }\end{array}$ \\
\hline Mud & 62 & $15 \cdot 3$ & 9.7 & $4 \cdot 3$ & $8 \cdot 7$ \\
\hline Muddy $\int_{\text {shell }}^{\text {no }}$ & $43 \cdot 6$ & $7 \cdot 3$ & $3 \mathrm{I} \cdot 5$ & $6 \cdot 5$ & II $\cdot \mathrm{I}$ \\
\hline sand $\left\{\begin{array}{c}\text { with } \\
\text { shell }\end{array}\right.$ & $43 \cdot 3$ & $15 \cdot 5$ & I3 & II 99 & $16 \cdot 3$ \\
\hline Fine shell gravel & 64 & $5 \cdot 2$ & $9 \cdot 2$ & II. 4 & $10 \cdot 2$ \\
\hline Fine stony gravel & 49 & $17 \cdot 7$ & $7 \cdot 7$ & $16^{4}$ & $9 \cdot 6$ \\
\hline Coralline gravel & 58 & $8 \cdot 4$ & 7 & $22 \cdot I$ & $4 \cdot 5$ \\
\hline Coarse shell gravel & - & - & - & - & - \\
\hline Large stones & - & - & - & - & - \\
\hline Clean sand & 60 & $2 \mathrm{I} \cdot 5$ & $17 \cdot 5$ & I & - \\
\hline Boring in shells & - & - & - & - & - \\
\hline Sponges & 二 & - & 二 & - & - \\
\hline Hydroids & - & - & - & - & - \\
\hline
\end{tabular}

\begin{tabular}{|c|c|c|c|c|}
\hline \multicolumn{2}{|c|}{$\begin{array}{l}\text { No. of specimens } \\
\text { per } \mathrm{m}^{2}\end{array}$} & \multicolumn{2}{|c|}{$\begin{array}{l}\text { No. of species } \\
\text { per station }\end{array}$} & \multirow{2}{*}{$\begin{array}{l}\text { Total } \\
\text { species }\end{array}$} \\
\hline Range & Mean & Range & Mean & \\
\hline $\begin{array}{l}26-109 \\
66-574\end{array}$ & $\begin{array}{r}56 \\
174\end{array}$ & $\begin{array}{l}4-12 \\
8-31\end{array}$ & $\begin{array}{r}7 \cdot 9 \\
19 \cdot 3\end{array}$ & $\begin{array}{l}27 \\
64\end{array}$ \\
\hline $95-368$ & 221 & $14-50$ & $3 I \cdot 6$ & 122 \\
\hline${ }^{50-466}$ & $\underline{342}$ & $\begin{array}{r}2 I-39 \\
6-45\end{array}$ & $\begin{array}{l}29 \\
24\end{array}$ & $\begin{array}{l}85 \\
66\end{array}$ \\
\hline${ }^{180-292}$ & 244 & $\begin{array}{r}18-3 I \\
2-13\end{array}$ & 27 & $\begin{array}{l}58 \\
27\end{array}$ \\
\hline - & 二 & $\begin{array}{r}2-13 \\
10-24\end{array}$ & $\overline{18}$ & $4 \mathrm{I}$ \\
\hline 120 & - & 3-19 & - & 27 \\
\hline$\overline{-}$ & - & I-I9 & 6.4 & 32 \\
\hline Z & - & $\begin{array}{c}6 \\
4-20\end{array}$ & $\overline{\text { II }} \cdot 5$ & $\begin{array}{r}0 \\
37\end{array}$ \\
\hline
\end{tabular}


TABLE 11. STATION LIST

\begin{tabular}{|c|c|c|c|c|c|c|}
\hline No. & Date & Position & $\begin{array}{c}\text { Depth } \\
\text { (fm.) }\end{array}$ & Bottom deposit & $\begin{array}{l}\text { Gear } \\
\text { used }\end{array}$ & $\begin{array}{l}\text { No. of } \\
\text { hauls }\end{array}$ \\
\hline I & 16. ii. 53 & I $\frac{1}{2}$ miles W. of Niarbyl & 15 & c.gr. \& m.s. & V-V.G. & 5 \\
\hline 2 & 16. ii. 53 & 4 miles W. of Niarbyl & 20 & m.s. \& sh.gr. & V-V.G. & 5 \\
\hline 3 & I6. ii. 53 & 5 miles W. of Niarbyl & 25 & m.s. \& sh.gr. & V-V.G. & 5 \\
\hline 4 & I6. ii. 53 & $5 \frac{1}{2}$ miles W. of Niarbyl & 30 & m.s. & V-V.G. & 5 \\
\hline 5 & 9. iii. 53 & I $\frac{1}{2}$ miles $\mathrm{W}$. of Niarbyl & I5 & c.gr. \& m.s. & V-V.G. & 5 \\
\hline 6 & 9. iii. 53 & $6 \frac{1}{2}$ miles W. of Niarbyl & 35 & m.s. & V-V.G. & 5 \\
\hline 7 & 9. iii. 53 & 7 miles W. of Niarbyl & 40 & m. & V-V.G. & 5 \\
\hline 8 & 9. iii. 53 & $8 \frac{1}{2}$ miles W. of Niarbyl & 45 & $\mathrm{~m}$. & V-V.G. & 5 \\
\hline 9 & 9. iii. 53 & IO $\frac{1}{2}$ miles W. of Niarbyl & 50 & m. & V-V.G. & 5 \\
\hline Io & 20. iv. 53 & $\frac{1}{2}$ mile N. of Fleshwick Bay & 9 & f.st.gr. & S.N.D. & I \\
\hline II & 20. iv. 53 & Fleshwick Bay & IO & f.st.gr. & S.N.D. & I \\
\hline 12 & I8. iv. 53 & I $\frac{1}{2}$ miles S. $80^{\circ} \mathrm{W}$. of Niarbyl & I5 & c.gr. \& m.s. & V-V.G. & 5 \\
\hline I3 & I8. iv. 53 & 4 miles S. $80^{\circ} \mathrm{W}$. of Niarbyl & 20 & m.s. \& sh.gr. & V-V.G. & 5 \\
\hline I4 & I8. iv. 53 & $5^{\frac{1}{2}}$ miles S. $80^{\circ}$ W. of Niarbyl & 30 & m.s. \& sh.gr. & V-V.G. & 5 \\
\hline I5 & I8. iv. 53 & 9 miles S. $80^{\circ} \mathrm{W}$. of Niarbyl & 40 & m. & V-V.G. & 5 \\
\hline I6 & I8. iv. 53 & Io miles S. $80^{\circ} \mathrm{W}$. of Niarbyl & 45 & $\mathrm{~m}$. & V-V.G. & 5 \\
\hline I7 & 27. viii. 53 & I2 miles S. $80^{\circ} \mathrm{W}$. of Peel & 50 & $\mathrm{~m}$. & V-V.G. & 5 \\
\hline I8 & 27. viii. 53 & I3 miles N.W. of the Sound & 55 & $\mathrm{~m}$. & V-V.G. & 5 \\
\hline I9 & 27. viii. 53 & 6 miles N. $55^{\circ} \mathrm{W}$. of the Sound & 30 & m.s. & V-V.G. & 5 \\
\hline 20 & I4. X. 53 & 3 miles W. of Bradda Head & 20 & sh.s. \& sh.gr. & V-V.G. & 3 \\
\hline $2 I$ & I4. x. 53 & $4 \frac{1}{2}$ miles W. of Sloc & 20 & sh.s. \& sh.gr. & V-V.G. & 3 \\
\hline 22 & I $4 . x \cdot 53$ & 4 miles W. of Niarbyl & 20 & m.s. \& sh.gr. & V-V.G. & 4 \\
\hline 23 & I4. x. 53 & 5 miles W. of Niarbyl & 25 & m.s. \& sh.gr. & V-V.G. & 5 \\
\hline 24 & I4. X. 53 & $5 \frac{1}{2}$ miles W. of Niarbyl & 30 & m.s. & V-V.G. & 5 \\
\hline 25 & I4. X. 53 & $5 \frac{1}{2}$ miles W. of Sloc & 25 & m.s. \& sh.gr. & V-V.G. & 5 \\
\hline 26 & I5. x. 53 & 5 miles W. of Bradda Head & 25 & sh.s. \& sh.gr. & V-V.G. & 5 \\
\hline 27 & I5.x. 53 & 6 miles W. of Bradda Head & 30 & sh.s. \& sh.gr. & V-VG. & 3 \\
\hline 28 & I5. X. 53 & 9 miles W. of Bradda Head & 29 & m.s. \& sh.gr. & V-V.G. & 3 \\
\hline 29 & I5. $x: 53$ & Io miles W. of Bradda Head & 40 & m.s. \& Turr.sh. & V-V.G. & 3 \\
\hline 30 & 24. xi. 53 & I $\frac{1}{2}$ miles W. of Niarbyl & I5 & c.gr. \& m.s. & S.N.D. & I \\
\hline $3 \mathrm{I}$ & 24. xi. 53 & $\frac{1}{2}$ mile W. of Niarbyl & Io & s. & S.N.D. & I \\
\hline 32 & 24. xi. 53 & $\frac{1}{2}$ mile S.S.W. of Niarbyl & Io & coarse st.gr. & S.N.D. & I \\
\hline 33 & 9. ii. 54 & I mile W. of Bradda Head & I7 & m.s. \& sh.gr. & S.N.D. & I \\
\hline 34 & 9. ii. 54 & 2 miles W. of Sloc & 15 & $\begin{array}{l}\text { large stones, } \\
\text { f.st.gr. \& m.s. }\end{array}$ & S.N.D. & I \\
\hline 35 & 9. ii. 54 & 3 miles W. of Sloc & I8 & m.s. \& sh.gr. & S.N.D. & I \\
\hline 36 & 9. ii. 54 & $9 \frac{1}{2}$ miles W. of Sloc & 40 & m.s. \& Turr.sh. & V-V.G. & 3 \\
\hline 37 & 9. ii. 54 & I I miles W. of Sloc & 50 & $\mathrm{~m}$ & V-V.G. & 3 \\
\hline $3^{8}$ & 9. ii. 54 & 7 miles W. of Sloc & 30 & m.s. \& sh.gr. & V-V.G. & 3 \\
\hline 39 & II. iii. 54 & Off P.E. breakwater & 5 & f.st.gr. & N.D. & I \\
\hline 40 & II. iii. 54 & $\frac{1}{4}$ mile W. of Charran & 16 & st.gr. & N.D. & I \\
\hline $4 \mathrm{I}$ & I. iv. 54 & 8 miles S. $80^{\circ} \mathrm{W}$. of Chicken R. & 35 & m.s. \& Turr.sh. & V-V.G. & 3 \\
\hline 42 & I. iv. 54 & Io miles S. $80^{\circ} \mathrm{W}$. of Chicken R. & 38 & $\mathrm{~m}$ & V-V.G. & 3 \\
\hline 43 & I. iv. 54 & I 2 miles S. $80^{\circ} \mathrm{W}$. of Chicken R. & 35 & m. & V-V.G. & 3 \\
\hline 44 & I. iv. 54 & 6 miles S. $80^{\circ} \mathrm{W}$. of Chicken R. & 34 & m.s. \& sh.gr. & S.N.D. & I \\
\hline 45 & I. iv. 54 & 4 miles S. $80^{\circ} \mathrm{W}$. of Chicken R. & 32 & m.s. \& sh.gr. & S.N.D. & I \\
\hline 46 & I. iv. 54 & 2 miles S. $80^{\circ} \mathrm{W}$. of Chicken $\mathrm{R}$. & 24 & shells \& sh.gr. & $4 \mathrm{ft} . \mathrm{D}$. & I \\
\hline 47 & I9. iv. 54 & I $\frac{1}{2}$ miles S. $10^{\circ} \mathrm{W}$. of Scarlet P. & 20 & stones & $4 \mathrm{ft} . \mathrm{D}$ & I \\
\hline 48 & I9. iv. 54 & 3 miles S. $60^{\circ} \mathrm{W}$. of Langness & $2 I$ & shells \& stones & $4 \mathrm{ft} . \mathrm{D}$. & I \\
\hline 49 & I9. iv. 54 & $2 \frac{3}{4}$ miles S. $15^{\circ} \mathrm{W}$. of P. St. M. & $2 \mathrm{I}$ & shells & $4 \mathrm{ft}$. D. & I \\
\hline 50 & I9. iv. 54 & I mile S.E. of Chicken R. & $25-30$ & stones & $4 \mathrm{ft} . \mathrm{D}$. & I \\
\hline $5 \mathrm{I}$ & I9. iv. 54 & 2 miles S. $22^{\circ} \mathrm{W}$. of Chicken R. & 24 & sh.gr. \& stones & $4 \mathrm{ft} . \mathrm{D}$. & I \\
\hline 52 & I9. iv. 54 & 2 miles N. $80^{\circ} \mathrm{W}$. of Chicken R. & 25 & sh.gr. \& shells & $4 \mathrm{ft} . \mathrm{D}$ & I \\
\hline 53 & I9. iv. 54 & $2 \frac{3}{4}$ miles S. $80^{\circ} \mathrm{W}$. of Bradda Head & $2 \mathrm{I}$ & shells & $4 \mathrm{ft} . \mathrm{D}$. & I \\
\hline 54 & I9. iv. 54 & $3 \frac{1}{2}$ miles S. $80^{\circ} \mathrm{W}$. of Bradda Head & $2 \mathrm{I}-24$ & shells & $4 \mathrm{ft} . \mathrm{D}$ & I \\
\hline 55 & 26. iv. 54 & I I miles N. $40^{\circ} \mathrm{W}$. of the Sound & 53 & $\mathrm{~m}$ & V-V.G. & 2 \\
\hline 56 & 26. iv. 54 & I3 miles N. $40^{\circ} \mathrm{W}$. of the Sound & 58 & $\mathrm{~m}$. & V-V.G. & 2 \\
\hline 57 & 26. iv. 54 & I 4 miles N. $40^{\circ} \mathrm{W}$. of the Sound & 65 & $\mathrm{~m}$. & V-V.G. & 2 \\
\hline 58 & 26. iv. 54 & I5 miles N. $40^{\circ} \mathrm{W}$. of the Sound & 70 & $\mathrm{~m}$. & V-V.G. & 2 \\
\hline
\end{tabular}


TABLE 11 (continued)

\begin{tabular}{|c|c|c|c|c|c|c|}
\hline No. & Date & Position & $\begin{array}{l}\text { Depth } \\
\text { (fm.) }\end{array}$ & Bottom deposit & $\begin{array}{l}\text { Gear } \\
\text { used }\end{array}$ & $\begin{array}{l}\text { No. of } \\
\text { hauls }\end{array}$ \\
\hline 59 & 26. iv. 54 & Port Erin Bay & $3-4$ & s. \& f.st.gr. & V-V.G. & 5 \\
\hline 60 & I2. v. 54 & 6 miles N. $60^{\circ} \mathrm{W}$. of the Sound & $3 I^{7}$ & m.s. \& sh.gr. & V-V.G. & 3 \\
\hline 6I & I2. v. 54 & 9 miles N. $60^{\circ} \mathrm{W}$. of the Sound & $4 \mathrm{I}$ & m.s. \& Turr.sh. & V-V.G. & 3 \\
\hline 62 & I2. v. 54 & IO $\frac{1}{2}$ miles N. $60^{\circ} \mathrm{W}$. of the Sound & 50 & m. & V-V.G. & 3 \\
\hline 63 & I2. v. 54 & I 5 miles N. $60^{\circ} \mathrm{W}$. of the Sound & 60 & m. & V-V.G. & 3 \\
\hline 64 & I2. v. 54 & $7 \frac{1}{2}$ miles N.W. of the Sound & 37 & m.s. & V-V.G. & 5 \\
\hline 65 & I3. xi. 53 & Port Erin Bay & $2-3$ & s. & N.D. & 2 \\
\hline 66 & 20. i. 54 & $\frac{1}{2}$ mile N. of the Sound & I5 & Chlamys opercularis & $4 \mathrm{ft} . \mathrm{D}$. & I \\
\hline 67 & I4. X. 52 & $\frac{1}{4}$ mile W. of Bradda Head & 12 & shells \& sh.gr. & 4 ft. D. & 2 \\
\hline 68 & 24. x. 52 & Bay Fine & I2 & shells & 4 ft. D. & I \\
\hline 69 & 5. xi. 52 & 5 miles S. of P. St. $M$. & 27 & Modiolus epif. & $4 \mathrm{ft}$. D. & I \\
\hline 70 & II. xi. 52 & I mile S. of Spanish Head & I7. & sh.gr. \& m.s. & S.N.D. & $\mathbf{I}$ \\
\hline $7 \mathrm{I}$ & II. xi. 52 & I mile N.N.W. of Bradda Head & $18 \frac{1}{2}$ & sh.gr. \& m.s. & S.N.D. & I \\
\hline 72 & II. xi. 52 & 2 miles S.W. of Chicken R. & 26 & shells \& sh.gr. & S.N.D. & I \\
\hline 73 & 28. vii. 53 & Bay Fine & I5 & Chlamys opercularis & 4 ft. D. & I \\
\hline 74 & $6 . x .53$ & Off P. E. breakwater & ro & rock & Trawl & \\
\hline 75 & I. xii. 52 & Fleshwick Bay & 6 & f.st.gr. & S.N.D. & I \\
\hline 76 & 30. ix. 52 & 7 miles N. $30^{\circ} \mathrm{W}$. of the Sound & 35 & m.s. & V-V.G. & Io \\
\hline 77 & 17. xi.: 52 & 7 miles N. $30^{\circ} \mathrm{W}$. of the Sound & 35 & m.s. & V-V.G. & 10 \\
\hline & 23. xii. 52 & 7 miles N. $30^{\circ} \mathrm{W}$. of the Sound & 35 & m.s. & V-V.G. & I0 \\
\hline
\end{tabular}

\section{Abbreviations}

Gear used: V-V.G., van Veen bottom sampler ( $\left.1 / 10 \mathrm{~m}^{2}\right)$; N.D., naturalist's dredge ( 2 ft. 6 in.); S.N.D., small naturalist's dredge ( $\mathrm{I}$ ft. 6 in.); 4 ft. D., $4 \mathrm{ft}$. scallop dredge.

Bottom deposit or contents of haul: c.gr., coralline gravel; f.st.gr., fine stony gravel; m., mud; m.s., muddy sand; s., sand; sh.s., shell sand; sh.gr., shell gravel; Turr.sh., empty shells of Turritella communis. 